\title{
A comparative study of age-related hearing loss in wild type and insulin-like growth factor I deficient mice
}

\author{
' Instituto de Investigaciones Biomedicas "Alberto Sols," CSIC-UAM, Madrid, Spain \\ 2 Centro de Investigación Biomédica en Red de Enfermedades Raras, Madrid, Spain \\ ${ }^{3}$ Departamento de Medicina y Cirugia, Facultad de Veterinaria, Universidad Complutense de Madrid, Madrid, Spain \\ 4 Departamento de Anatomia, Facultad de Veterinaria, Universidad Complutense de Madrid, Madrid, Spain \\ ${ }^{5}$ Centro de Investigaciones Biologicas, CSIC, Madrid, Spain \\ ${ }^{6}$ Centro de Investigacion Biomedica en Red de Diabetes y Enfermedades Metabolicas, Madrid, Spain \\ 7 Servicio de Alergia, Hospital General Universitario Gregorio Marañon, Madrid, Spain
}

Raquel Riquelme ${ }^{1+}$, Rafael Cediel ${ }^{1,2,3 t}$, Julio Contreras ${ }^{1,2,4 t}$, Lourdes Rodriguez-de la Rosa ${ }^{1,2}$, Silvia MurilloCuesta $^{1,2}$, Catalina Hernandez-Sanchez ${ }^{5,6}$, Jose M. Zubeldia ${ }^{2,7}$, Sebastian Cerdan ${ }^{1}$ and Isabel Varela-Nieto ${ }^{1,2 *}$

\section{Edited by:}

Miguel A. Merchán, Universidad de Salamanca, Spain

Reviewed by:

Matthew C. Holley, The University of Sheffield, UK

Julie A. Chowen, Hospital Infantil Universitario Niño Jesús, Spain

\section{${ }^{*}$ Correspondence:}

Isabel Varela-Nieto, Instituto de

Investigaciones Biomédicas "Alberto Sols," CSIC-UAM, Arturo Duperier 4

28029 Madrid, Spain.

e-mail: ivarela@iib.uam.es

${ }^{\dagger}$ Raquel Riquelme, Rafael Cediel and Julio Contreras have contributed equally to this work.
Insulin-like growth factor-I (IGF-I) belongs to the family of insulin-related peptides that fulfils a key role during the late development of the nervous system. Human IGF1 mutations cause profound deafness, poor growth and mental retardation. Accordingly, lgf1--- null mice are dwarfs that have low survival rates, cochlear alterations and severe sensorineural deafness. Presbycusis (age-related hearing loss) is a common disorder associated with aging that causes social and cognitive problems. Aging is also associated with a decrease in circulating IGF-I levels and this reduction has been related to cognitive and brain alterations, although there is no information as yet regarding the relationship between presbycusis and IGF-I biodisponibility. Here we present a longitudinal study of wild type $/ \mathrm{gf} 1^{+/+}$and null $/ g f 1^{-/-}$mice from 2 to 12 months of age comparing the temporal progression of several parameters: hearing, brain morphology, cochlear cytoarchitecture, insulin-related factors and IGF gene expression and IGF-I serum levels. Complementary invasive and non-invasive techniques were used, including auditory brainstem-evoked response (ABR) recordings and in vivo MRI brain imaging. I ff $^{-1-}$ null mice presented profound deafness at all the ages studied, without any obvious worsening of hearing parameters with aging. $\lg \mathrm{f}^{+1+}$ wild type mice suffered significant age-related hearing loss, their auditory thresholds and peak I latencies augmenting as they aged, in parallel with a decrease in the circulating levels of IGF-I. Accordingly, there was an age-related spiral ganglion degeneration in wild type mice that was not evident in the Igf1 null mice. However, the Igf1-- null mice in turn developed a prematurely aged stria vascularis reminiscent of the diabetic strial phenotype. Our data indicate that IGF-I is required for the correct development and maintenance of hearing, supporting the idea that IGF-I-based therapies could contribute to prevent or ameliorate age-related hearing loss.

Keywords: aging, auditory brainstem responses, deafness, lgf1/- null mouse, insulin-like factors, in vivo brain imaging presbycusis, sensorineural deafness

\section{INTRODUCTION}

Neural development and the activity of the nervous system are regulated by a complex network of local and systemic factors. Insulin-like growth factors are fundamental modulators of nervous system structure, proliferation, growth, differentiation and metabolic demands during fetal and postnatal development (LeRoith, 2008). In mammals, the insulin gene family is comprised of three factors, insulin and the insulin-like growth factors I and II, which are recognized by three receptors (Varela-Nieto et al., 2007). These factors and receptors are expressed in neural cells during development in specific spatiotemporal patterns. Insulin-like growth factor-I (IGF-I) expression peaks in the nervous system during late embryonic and neonatal periods. While its expression is reduced in the adult but it is maintained in areas of high plasticity such as the olfactory bulb and the hippocampus (Aleman and Torres-Aleman, 2009; Aberg, 2010). In the adult brain, IGF-I is essential to maintain normal brain physiology and to promote neurogenesis (Sun and
Bartke, 2007; Llorens-Martin et al., 2009). Partial or total IGF-I deficit is associated with severe alterations to the nervous system and disease. In humans, different mutations in the IGF1 gene produce the functional loss of this protein, a genetic condition associated with the presence of severe intrauterine and postnatal growth impairment, microcephaly, mental retardation and sensorineural deafness, among other problems (Woods et al., 1997; Bonapace et al., 2003; Walenkamp et al., 2005; Walenkamp and Wit, 2007; Netchine et al., 2009). Indeed, sensorineural hearing loss is associated with poor growth rates in infancy and adolescence (Welch and Dawes, 2007), adult short stature (Barrenas et al., 2005) and Turner's syndrome (Barrenas et al., 2000).

Accordingly, mice lacking the Igfl gene suffer severe growth defects that are coupled to diminished survival and delayed nerve myelination, among other alterations (D'Ercole et al., 2002; Zeger et al., 2007). We have shown that cochlear gene expression is affected in the $\operatorname{Igf1^{-/-}}$ null mouse, this organ displaying morphological 
alterations (Camarero et al., 2001, 2002; Sanchez-Calderon et al., 2010) associated with bilateral hearing loss at the age of 1 month in these mice (Cediel et al., 2006).

In humans, IGF-I levels are highest during puberty and they decline with age (Leifke et al., 2000; Gomez, 2007). Aging is associated with a reduction in certain cognitive functions, such as hearing loss, and the onset of diseases like atherosclerosis and Alzheimer's disease (Dik et al., 2003; Watanabe et al., 2005). Similarly, changes in circulating IGF-I levels are also correlated with cognitive performance in older humans, as well as with the onset of age-related neurodegenerative diseases. For example, serum IGF-I levels are diminished in Alzheimer's disease and in other degenerative brain disorders, whereas there is an up-regulation after brain injury, suggesting that IGF-I is involved in neuroprotection (Torres-Aleman, 2008). Since recombinant human IGF-I therapy has been approved in humans to treat poor linear growth, several groups have contemplated the use of rhIGF-I in animal models of brain insults to explore its utility as a protective or neural repair agent (Bright et al., 2009; Torres-Aleman, 2010).

The genetic component of hearing loss is very diverse and involves hundreds of different genes (Dror and Avraham, 2009). Age-related hearing loss (ARHL - presbycusis) is the most common cause of adult auditory deficiency. It is usually a sensorineural hearing disorder in which hair cells and auditory nerve cells in the inner ear are damaged or lost. The genetic and molecular bases of susceptibility to ARHL are largely unknown and only a few genes that influence late onset or progressive hearing loss have been discovered (van Wijk et al., 2003; Zhu et al., 2003; Van Eyken et al., 2007; Dror and Avraham, 2009). However, many of these genes are likely to be linked to the aging and neurodegeneration related to susceptibility to oxidative stress, excitotoxicity and cell death (Holley, 2002).

IGF-I signaling regulates lifespan, apoptosis, sensitivity to oxidative stress and the programmed response to DNA damage across species (Christensen et al., 2006; Niedernhofer et al., 2006; Sanchez-Calderon et al., 2007; Narasimhan et al., 2009). Despite the importance of IGF-I in both aging and deafness, the influence of an IGF-I deficit in age-related hearing loss has not yet been studied. Here, we have carried out a longitudinal study of auditory function, cochlear and brain morphology, and IGF-I levels in wild type and $I g f 1^{-1-}$ null mice to study the relationship between IGF-I deficit and hearing performance during aging. Our findings support the idea that IGF-I levels may predict premature age-related hearing loss.

\section{MATERIALS AND METHODS MOUSE HANDLING AND GENOTYPING}

Heterozygous mice with a targeted disruption of the Igfl gene were bred and maintained on a hybrid MF1 and 129/sv mouse genetic background to increase nullizygous Igf1 mutant survival (Liu et al., 1993). Null mouse mortality before adulthood is high, although between 20 and 30\% survived. Both wild type and null mice were studied at the time points indicated to follow their progression from young adults ( 1 month) to aged mice (1 year). Mouse genotypes were identified using the REDExtract$\mathrm{N}$-Amp ${ }^{\mathrm{TM}}$ Tissue PCR Kit (XNAT, Sigma) according to the manufacturer's instructions. The PCR was conducted with the following thermal cycle program: 1 cycle of $94^{\circ} \mathrm{C}$ for $10 \mathrm{~min} ; 30$ cycles of $94^{\circ} \mathrm{C}$ for $1 \mathrm{~min}, 59^{\circ} \mathrm{C}$ for $1 \mathrm{~min}, 72^{\circ} \mathrm{C}$ for $1 \mathrm{~min}$; and a final elongation step at $72^{\circ} \mathrm{C}$ for $10 \mathrm{~min}$. The wild type $\operatorname{Igf} 1$ allele was detected using the $5^{\prime}$-GTCTAACACCAGCCCATTCTGATT- $3^{\prime}$ and 5'-GACTCGATTTCACCCACTCGATCG-3' primers, which produced a 250-bp amplicon. The neomycin cassette was detected using primers $5^{\prime}$-GCTTGGGTGGAGAGGCTATCC- $3^{\prime}$ and 5'-CCAGCTCTTCAGCAATATCACGGG-3', producing a 658-bp band. All primers were used simultaneously with no evidence of interference. All animal handling procedures were carried out in accordance with the European Council Directive (86/609/ECC) and with the approval of the Bioethics Committee of the CSIC.

\section{AUDITORY BRAINSTEM RECORDING (ABR)}

Mice were anesthetized by i.p. administration of ketamine (Ketolar () 50, Parke Davis Labs, $100 \mathrm{mg} / \mathrm{kg}$ ) and xylazine (Rompum $\odot 2 \%$, Bayer Labs, $4 \mathrm{mg} / \mathrm{kg}$ ), and they were maintained at $37^{\circ} \mathrm{C}$ throughout the testing period to avoid hypothermia. Both female and male mice were used; no sex-associated parameters were identified in this study. ABR was carried out in a sound-attenuating chamber in an electrically shielded room. Stimulus presentation, ABR amplification and data acquisition were performed with TDT System $3^{\mathrm{TM}}$ equipment and SigGeRPTM ${ }^{\mathrm{TM}}$ software (Tucker Davis Technologies, Alachua FL 32615), as described previously (Cediel et al., 2006). Briefly, an ES-1 electrostatic speaker was placed $10 \mathrm{~cm}$ from the animal's head and its hearing of different sound stimuli was tested. Toneburst stimuli $(4,8,16$ and $32 \mathrm{kHz})$, with a 1 -ms rise/fall time and a 5 -ms plateau, or click stimuli $(1-16 \mathrm{kHz})$ were applied. Stimuli were presented at decreasing intensities in steps from $90 \mathrm{~dB}$ SPL to $10 \mathrm{~dB}$ SPL until no waveform was obtained. The stimulus intensity was then increased in $5 \mathrm{~dB}$ SPL steps and two more responses were recorded in order to determine the auditory threshold. Auditory profiles were recorded using stainless steel needle electrodes (Spes Medica S.r.l., 20090 Milan, Italy) placed as follows: vertex-positive, mastoid area-negative and hip-ground. Responses were collected and amplified by a factor of $1 \times 10^{6}$, and the system was calibrated as recommended by the manufacturer with an ACO Pacific ${ }^{\mathrm{TM}} 1 / 4$ inch microphone connected to a specific TDT calibration module. We analyzed the following parameters obtained from waves registered during the ABR tests: auditory thresholds, latencies of peaks I-V and interpeak latencies.

\section{MAGNETIC RESONANCE IMAGING (MRI) AND VOLUME ESTIMATES}

MRI of the brains from wild type $I g f 1^{+++}$and $I g f 1^{-/-}$null mice was performed with a 7-T Bruker PharmaScan ${ }^{\mathrm{TM}} 7 \mathrm{~T}$. T1 or T2 weighted images were acquired using the spin-echo sequence with values of $\mathrm{TR}=300 \mathrm{~ms} / \mathrm{TE}=10 \mathrm{~ms}$ or $\mathrm{TR}=2500 \mathrm{~ms} / \mathrm{TE}=60 \mathrm{~ms}$, respectively. One day prior to the MRI experiments, animals were subcutaneously injected with a $30-\mathrm{mM}$ solution of $\mathrm{MnCl}_{2}$ at a dose of $0.4 \mathrm{mmol} / \mathrm{kg}$ body weight. Manganese is a positive MRI contrast agent that is taken up in brain regions with higher neuronal activity (McDaniel et al., 2001; Watanabe et al., 2004; Uchino et al., 2007). T1- and T2-weighted images were obtained every $1.1 \mathrm{~mm}$ and volume estimates were obtained according to the principle of Cavalieri (Gundersen and Jensen, 1987; Camarero et al., 2001). The Cavalieri principle of systematic sampling in combination with point counting is considered a reliable and efficient method to 
estimate volumes in MRI (Jelsing et al., 2005). The points hitting the surface area of the cerebellum, brainstem, olfactory bulb and total brain were counted for each MRI section.

\section{COCHLEAR MORPHOLOGY}

Mice were anesthetized by i.p. injection of $0.12 \mathrm{mg} / \mathrm{g}$ ketamine hydrochloride and perfused transcardially with $4 \%$ paraformaldehyde in $0.1 \mathrm{M}$ phosphate-buffered saline (PBS) [pH 7.4]. The animal's brain was removed and weighed after separating the medulla at the beginning of the spinal cord. Temporal bones were isolated, post-fixed for 1 day, decalcified in $0.3 \mathrm{M} \mathrm{EDTA} \mathrm{[pH} \mathrm{6.5]}$ for 10 days and finally embedded in paraffin or gelatin. Paraffin sections $(10 \mu \mathrm{m})$ or cryosections $(20 \mu \mathrm{m})$ of temporal bones from $I g \mathrm{fl}^{+/+}$and $I g \mathrm{fl}^{-{ }^{--}}$mice were processed for Nissl staining, hematoxylin/eosin or other techniques to study their cytoarchitecture. Serial sections were collected to detect the $\mathrm{Na}^{+} \mathrm{K}^{+}$-ATPase $\beta 2$ isoform (rabbit anti-NaK-ATPase, Upstate Biotechnology, dilution 1:200) and Kir4.1 (rabbit anti-KCNJ10, Chemicon International, dilution 1:200), and phalloidin histochemistry was also performed (Alexa488 conjugated phalloidin, Molecular Probes, Invitrogen, Carlsbad, CA, USA, dilution 1:100: Murillo-Cuesta et al., 2009, 2010a, 2010b; Sanchez-Calderon et al., 2010). For immunohistochemistry, paraffin sections were processed by the avidin-biotin-peroxidase $(A B C)$ method using 3,3-DAB as chromogen.

\section{RNA ISOLATION AND QUANTITATIVE RT-PCR}

Total RNA was isolated using the Trizol reagent (Invitrogen) from the brainstem (BS), olfactory bulb (OB), cerebellum (CBL) and the remainder of the telencephalon-diencephalon (TD) of at least three to five postnatal day P90 mice per genotype. The purity of the RNA was assessed with an Agilent Bioanalyzer 2100 (Agilent Technologies). The reverse transcriptase reaction (RT) was typically performed on $5 \mu \mathrm{g}$ RNA with the Superscript III Kit and random primers (Invitrogen). Quantitative PCR (RT-PCRq) was performed with the ABI Prism 7900HT Sequence Detection System (Applied Biosystems, Weiterstadt, Germany) using the TaqMan Universal PCR Master Mix, No AmpErase UNG (Applied Biosystems) and probes from the Universal Probe Library (UPL: Roche Applied Science). The primer sequences used and the respective UPL probes were: Igfl Universal ProbeLibrary probe: \#67 (left primer CCGAGGGGCTTTTACTTCA and right primer CACAATGCCTGTCTGAGGTG); Igf2 Universal ProbeLibrary probe: \#40, (left primer CGCTTCAGTTTGTCTGTTCG and right primer GCAGCACTCTTCCACGATG; Igfir Universal ProbeLibrary probe: \#55 (left primer CCTGAAGAACCTTCGTCTCATC and right primer TGGTTGTCTAGGACATAGAAGGAGT); and 18 rRNA Universal ProbeLibrary probe: $\# 70$ (left primer TGCGAGTACTCAACACCAACA and right primer: TTCCTCAACACCACATGAGC). Assays were carried out according to the manufacturer's instructions and using the expression levels of eukaryotic $18 \mathrm{~S}$ rRNA as a reference. The data are presented in arbitrary units.

\section{DETERMINATION OF SERUM IGF-I LEVELS BY ELISA}

The concentration of circulating IGF-I was measured in serum samples taken at the times indicated using a standard OCTEIA Rat/Mouse IGF-I kit (sensitivity $63 \mathrm{ng} / \mathrm{ml}$ and variability
4-8\%) (IDS Ltd., Boldon, UK) according to the manufacturer's recommendations. Briefly, mouse serum samples were incubated with a reagent to inactivate binding proteins, and then diluted for the assay. These diluted samples were then incubated for $2 \mathrm{~h}$ at room temperature with a biotinylated polyclonal rabbit anti-rat IGF-I antiserum, in polystyrene microtiter wells coated with purified monoclonal anti-Rat IGF-I antibodies. The wells were washed and horseradish peroxidase-labeled avidin was added. After further washing, tetramethyl-benzidine was added to develop the color reaction and the absorbance of the developed reaction was read at dual wavelength (A450-A650 nm). ELISA data are expressed in $\mathrm{ng} / \mathrm{ml}$. Statistical comparisons of IGF-I sera levels between the different age groups were performed with a Mann-Whitney rank sum test using GraphPad InStat 3.06 (Software Inc., San Diego, CA, USA). The results were considered to be statistically significant when $P<0.05$.

\section{STATISTICAL ANALYSIS}

Unless indicated otherwise, statistical analysis was performed with one-way ANOVA followed by Bonferroni adjustment as post hoc method, using SPSS ${ }^{\mathrm{TM}} 12$ software. The results were considered significant at $P<0.05$ and the data are presented as mean \pm s.e.m. Where indicated the Pearson product moment correlation coefficient $(r)$ was used as a measure of the linear dependence between two variables, $r$ values are between +1 and -1 and 0 indicates no correlation. Specific records are represented with Origin ${ }^{\mathrm{TM}}$ 7.0 software.

\section{RESULTS TEMPORAL PATTERN OF AGE-RELATED HEARING LOSS IN IGF1--- NULL AND IGF ${ }^{++}$WILD TYPE MICE}

Hearing was tested in mice using ABR evoked by transient click and tone-burst stimuli in 1, 3, 6, 9 and 12-month-old $I g f 1^{-/-}$null and $I g f I^{+/+}$wild type littermates. The ABR curves obtained for the mice of either genotype showed the characteristic five peaks during the 10-ms post-stimulus period at all the ages studied (Figure 1). The ABR thresholds in response to click stimuli were 40 and $35 \mathrm{~dB}$ SPL in 1- and 3-month-old wild type mice, respectively, and they increased steadily to a mean value of $75 \mathrm{~dB}$ SPL in 1-year-old mice (Figures 1 and 2A). A different pattern of aging was reflected by the auditory click-ABR thresholds in the Igf $1^{-l-}$ null mice. Young, 1- to 3-month-old Igf1 $1^{-/}$mice were profoundly deaf and had a mean auditory threshold of $70 \mathrm{~dB}$ SPL, which remained constant as they aged since 1-year-old mice had a threshold of $75 \mathrm{~dB}$ SPL (Figure 2A). Hence, while the $I g \mathrm{fl}^{+/+}$mice had significantly lower auditory thresholds than the Igf1 $1^{-1-}$ mice at younger ages (1-6 months), as the mice aged their ABR thresholds converged to reach a similar value at 1 year of age (Figure 2A).

Pure tone audiograms were obtained in the same mice at the frequencies of 4, 8, 16 and $32 \mathrm{kHz}$ using tone-burst ABR stimuli. At all ages tested, the general shape of the audiogram was similar in both mouse genotypes, and while the ABR peaks I to IV were clearly identified, peak $\mathrm{V}$ could only be distinguished in some recordings. The lowest threshold was obtained at $16 \mathrm{kHz}$, the best frequency for hearing in both the $I g f 1^{+/+}$and $I g f 1^{-/-}$mice at the ages studied (Figure 2B). At all four frequencies tested, an age-related increase in the thresholds was evident in $I g \mathrm{fl}^{+++}$mice, whilst the audiograms 


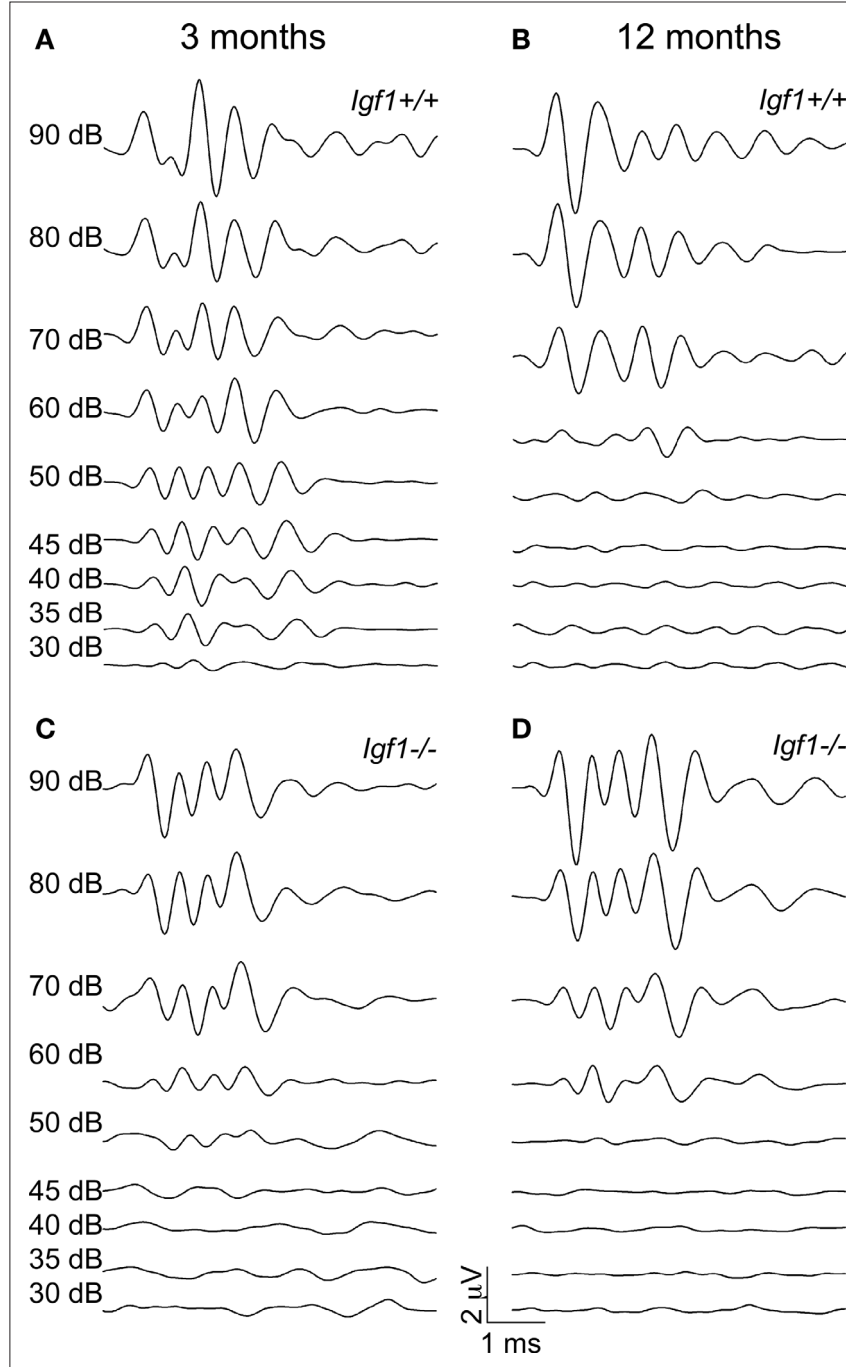

FIGURE 1 |ABR wave recordings from representative 3- and 12-month-

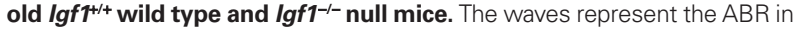
response to intensities of click stimuli decreasing from $90 \mathrm{~dB} S P L$ to $30 \mathrm{~dB}$ $S P L$ of a representative mouse for each condition. $(\mathbf{A}, \mathbf{B}) \mathrm{ABR}$ waves from

3- (A) and 12- (B) month-old /gf $11^{+++}$mice. (C,D) ABR waves from 3- (C) and 12(D) month-old $/$ gf $1^{-1-}$ mice. In (A) and (C) the intensity of the stimulus for each response is indicated, and the range of intensities is the same in (B) and (D).

from $\operatorname{Ig} f 1^{-/-}$null mice corresponded to profoundly deaf animals from the youngest age tested. Like the click stimuli, the tone-burst hearing thresholds were similar in 12-month-old $\mathrm{Ig} f 1^{+/+}$and $\mathrm{Ig} \mathrm{fl}^{-/-}$ mice, both genotypes showing ABR thresholds corresponding to profound deafness, although a small number of $\operatorname{Igf1^{-/}}$ and wild type mice had hearing thresholds above the electrostatic speaker driver limit (90 dB SPL). The ABR data were further analyzed to calculate the percentage of mice in each of the five age groups tested with thresholds above the normal hearing threshold value of $50 \mathrm{~dB}$ SPL (Figure 2C). There was a progressive increase with age of the proportion of $I g \mathrm{fl}^{+/+}$mice with moderate to profound deafness, and while at 6 months of age $50 \%$ of the mice tested had auditory thresholds over $50 \mathrm{~dB}$ SPL, that figure reached $100 \%$ by 9 months of age. By contrast, the entire population of $I g f 1^{-/-}$mice presented hearing deficiencies at all the ages studied (Figure 2C).

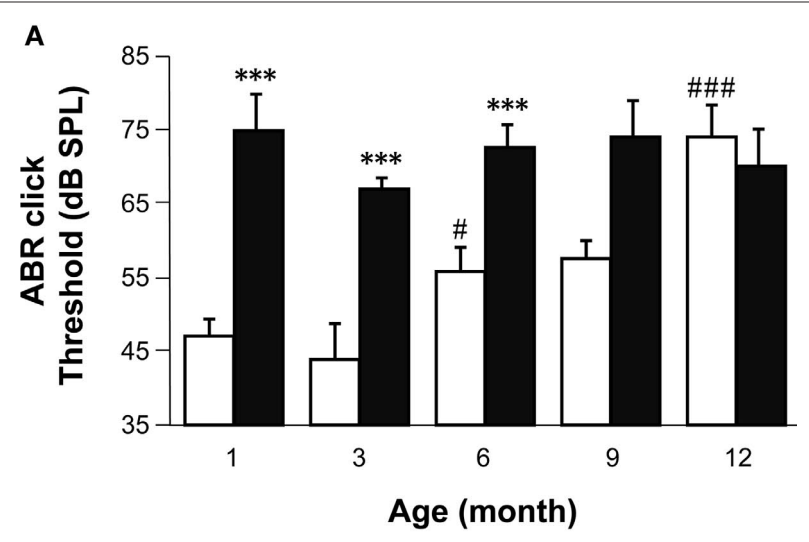

B

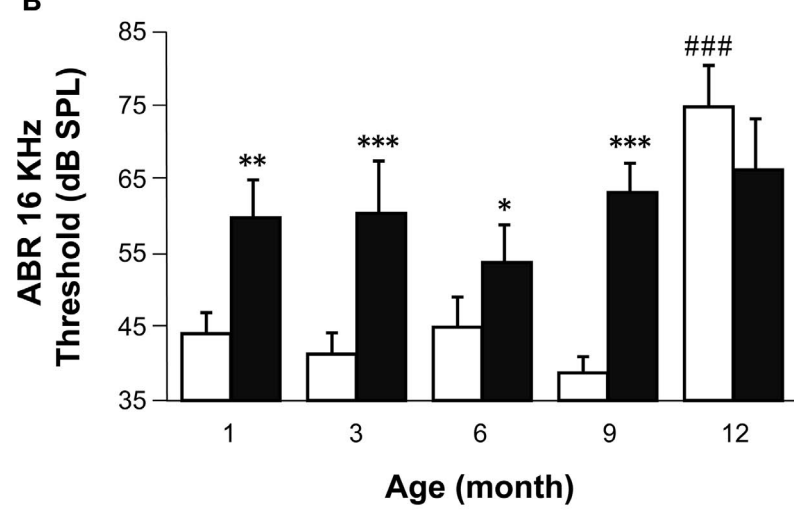

C

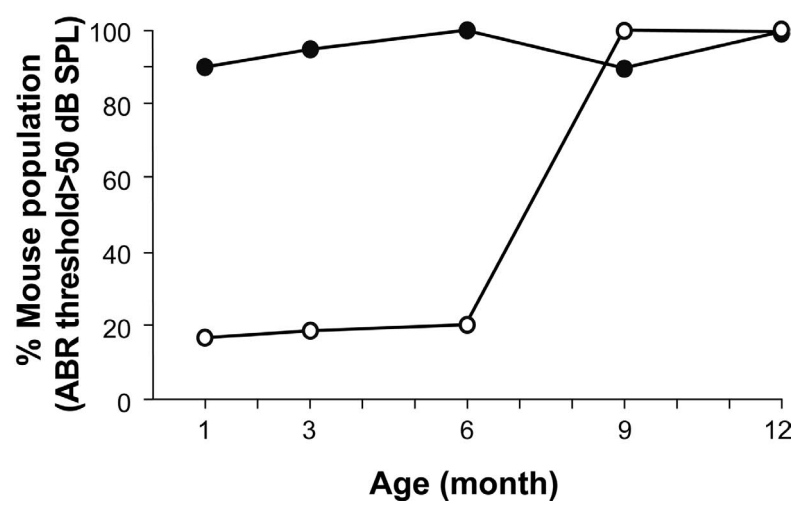

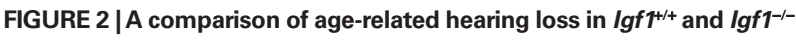
mice. (A) ABR thresholds in response to click stimulus in $/ \mathrm{gf1}^{+/+}$(open bars) and I $/ \mathrm{f}^{-1-}$ mice (closed bars) at different ages (1, 3, 6, 9 and 12 months). Wild type mice show an age-related increase in ABR thresholds, whereas the null mutant mice were deaf from the youngest age studied. (B) ABR responses to a $16 \mathrm{kHz}$ stimuli were obtained at the same ages and showed a similar trait. (C) Percentage of individuals for each genotype showing ABR thresholds above normal hearing ( $\geq 50 \mathrm{~dB}$ SPL) at each of the ages studied. Wild type and null mice are represented as open and closed circles, respectively. Statistical analysis was performed with ANOVA and post hoc Bonferroni and Dunnet tests. Data are presented as the mean \pm s.e.m; ${ }^{*}$ indicates comparison between genotypes ${ }^{*}{ }^{*} P<0.001$, ${ }^{*} P<0.01$ and ${ }^{*} P<0.05$; $*$ indicates comparison between consecutive ages $\# \# P<0.001$. The number $(n)$ of mice studied were 15, 13, 9, 8 and 7 wild type mice of 1, 3, 6, 9 and 12 month old, respectively; and 10,11,10, 6 and 5 null mice of the same ages. 
The absolute ABR peak latencies increased with age in both $I g f 1^{+/+}$and $I g f 1^{-/-}$null mice (Figure 3). For the sake of simplicity and to reflect the $\mathrm{ABR}$ response in the peripheral auditory and central nervous system, data were only plotted for peaks I and IV (Figures 3A,B), the latencies of which can be considered as a readout of auditory nerve and auditory BS functions, respectively (Ponton et al., 1996). At all ages tested, the peak latencies were delayed in
Igf $1^{-/-}$mice when compared with wild type mice (Figures $3 \mathbf{A}, \mathbf{B}$ ). The Peak I latency differences between wild type and $I g f 1^{-/-}$mice became progressively shorter as the mice aged, differences that were significant $(P<0.05)$ at 3 and 6 months of age (Figure 3$)$. The mean latency of peak IV followed a similar trend. Interestingly, mice of both genotypes showed a steeper increase in the peak I and IV latencies between 3 and 6 months of age. The age-related increase

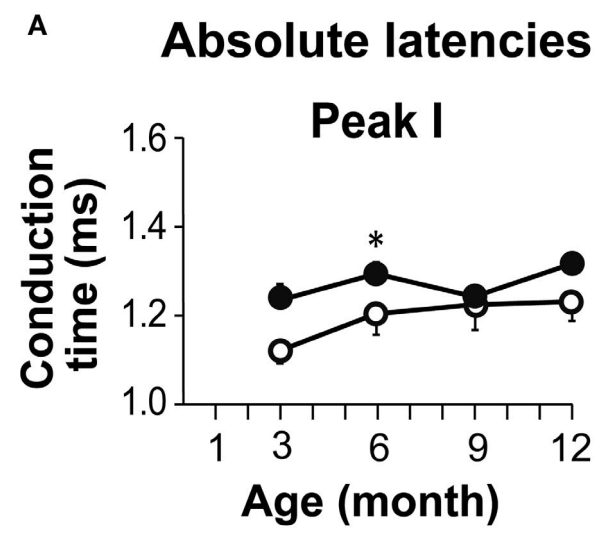

B

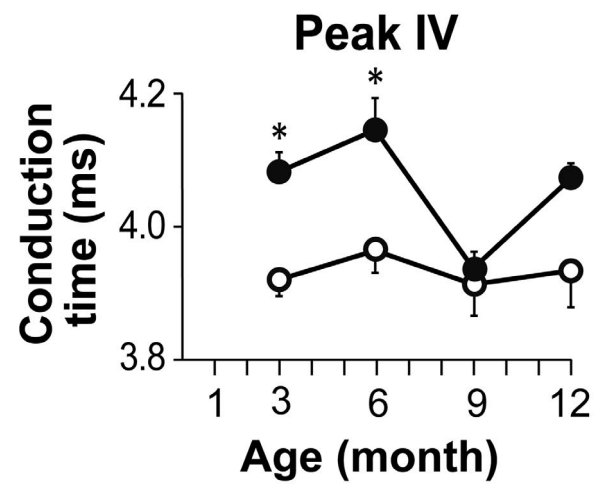

C

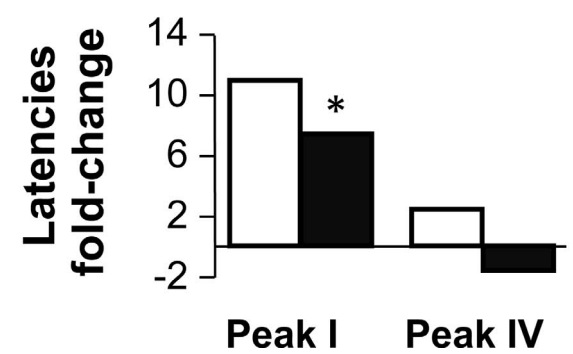

FIGURE 3 | Age-related changes in absolute and interpeak latencies in both genotypes. (A,B) Absolute Peak I (A) and peak IV (B) latencies obtained at $80 \mathrm{~dB}$ SPL. Absolute latencies are plotted for $\operatorname{lgf} 1^{+1++}$ (open circles) and $/ \mathrm{gf} 1^{-1}$ mice (closed circles) aged from 3 to 12 month old. (C) Percentage delay in latency with aging. Open and closed bars indicate wild type and null mice, respectively. The bars represent the percentage latency increase from 3 to 12 months of age for peaks I (bars to the left) and IV (bars to the right). The asterisk indicates that the $11 \%$ difference in peak I latency between 3- and
D Interpeak latencies

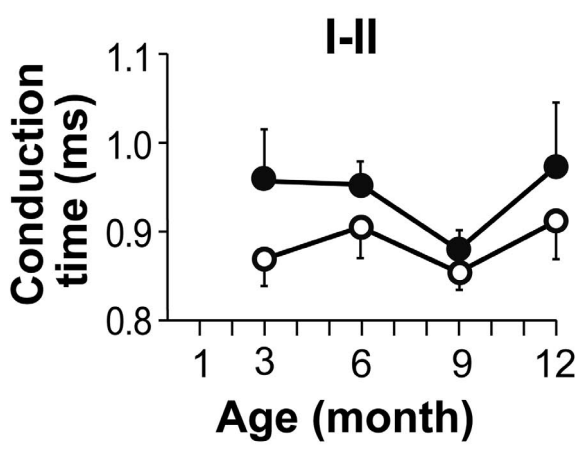

E

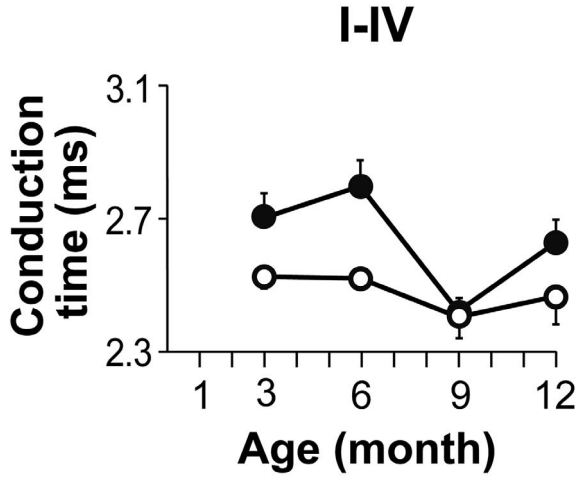

$\mathbf{F}$

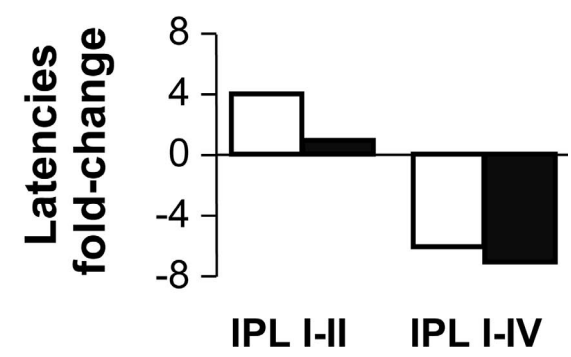

12-month-old wild type mice is significant $(P<0.05)$. Data are presented as the mean \pm s.e.m. (D,E) Interpeak latencies (IPL) I-II (D) and I-IV (E) obtained at $80 \mathrm{~dB}$ SPL for $\operatorname{lgf1^{+/+}}$ (open circles) and $/ g f 1^{-/-}$mice (closed circles) aged from 3 to 12 months old. (F) Percentage IPL increases with aging. As in (C), for wild type (open bars) and null mice (closed bars), the IPL I-II is shown by the bars on the left and IPL I-IV in the bars on the right. The number $(n)$ of mice studied was: 7, 9, 4 and 5 wild type and 6, 6, 6 and 3 null mice of 3, 6, 9 and 12 month old, respectively. 
in latency did not affect peaks I and IV in the same way, nor were the changes similar in $I g f 1^{+/+}$and $I g f 1^{-/-}$mice. Wild type $I g f 1^{+/+}$mice experienced a larger age-related change in latency between 3 to 12 months of age, that was $11 \%$ for peak I $(P<0.05)$. By contrast, the peak I latency did not increase significantly in $I g f 1^{-1-}$ mice over the same period. Peak IV presented smaller age-related changes in both genotypes (Figure 3C).

The interpeak latencies (IPL) reflected the transmission of auditory information along the auditory pathway. The interval between peaks I and II is assumed to represent the conduction time in the auditory nerve axons and therefore, this value provides information about the peripheral auditory system. On the other hand, the value between peaks I and IV reflect axonal transmission along the BS, offering information on the central auditory system. These IPL were longer in $I g f 1^{-/-}$mice than in $I g f 1^{+/+}$mice at all the ages tested (Figures 3D,E), although in neither genotype were significant changes in the IPL evident at any age (Figure 3F).

To further compare the temporal profile of hearing, the relationship between age and auditory thresholds was assessed for both mouse genotypes using product moment Pearson correlation coefficients. A clear correlation was observed between both these parameters in the $I g f 1^{+/+}$animals (Figure 4A) but not in the $I g f 1^{-/-}$ mice (Figure 4B). The correlation was less clear between aging and the increase in peak I latency as indicated by the product moment Pearson correlation coefficient, which was not statistically significant in $I g f 1^{+/+}$wild type and $I g f 1^{-/-}$null mice (Figures 4C,D) Since both the absolute latency for peak I and the auditory thresholds increased with age, the peak latency increase could be caused by the increase in the auditory threshold and not by aging. Product moment Pearson correlation coefficients were obtained between data pairs of auditory thresholds and absolute peak I latencies values for both genotypes at all the ages studied (Figures 4E,F). Accordingly, a significant correlation between auditory thresholds and cochlear nerve time conductions were observed in $\mathrm{Ig} \mathrm{fl}^{+/+}$ (Figure 4E) but not in Igf1 ${ }^{-/-}$mice (Figure 4F).

\section{AGE-RELATED REDUCTION IN THE DENSITY OF SPIRAL GANGLION NEURONS IN IGF ${ }^{1++}$ WILD TYPE MICE AND DEGENERATION OF THE STRIA VASCULARIS IN THE IGF1--- NULL MICE}

Important cochlear alterations were evident in 1-month-old $\mathrm{Ig} \mathrm{fl}^{-/-}$ mice that included reduced cochlear volume, neuronal loss, hypomyelinization, an immature tectorial membrane and a general delay in cell differentiation with increased presence of embryonic cell markers (Camarero et al., 2001, 2002; Sanchez-Calderon et al., 2010). Here, the morphology of the cochlea in 3-, 7- and 12-month-old $I g f 1^{+/+}$and $I g f 1^{-/-}$mice was analyzed. Generally, the cochlear cytoarchitecture was similar in both genotypes at the ages studied, although the differences reported in cochlear size were maintained between both mouse genotypes. Damage to the cochleae was evident in individual mice, although in general most mice had intact inner and outer hair cells, and the general cochlear structure was preserved until 1 year of age, the oldest mice studied (Figures 5A,B; Figure S1 in Supplementary Material). By contrast, there were fewer spiral ganglion neurons in 1-year old than in the younger $I g f 1^{+/+}$mice (Figures 5C,E,G), resulting in a similar density of neurons in 1-year-old mice from both genotypes (Figures 5C-H). Hence, $\operatorname{Ig} f 1^{+/+}$mice suffer a loss of spiral gan-
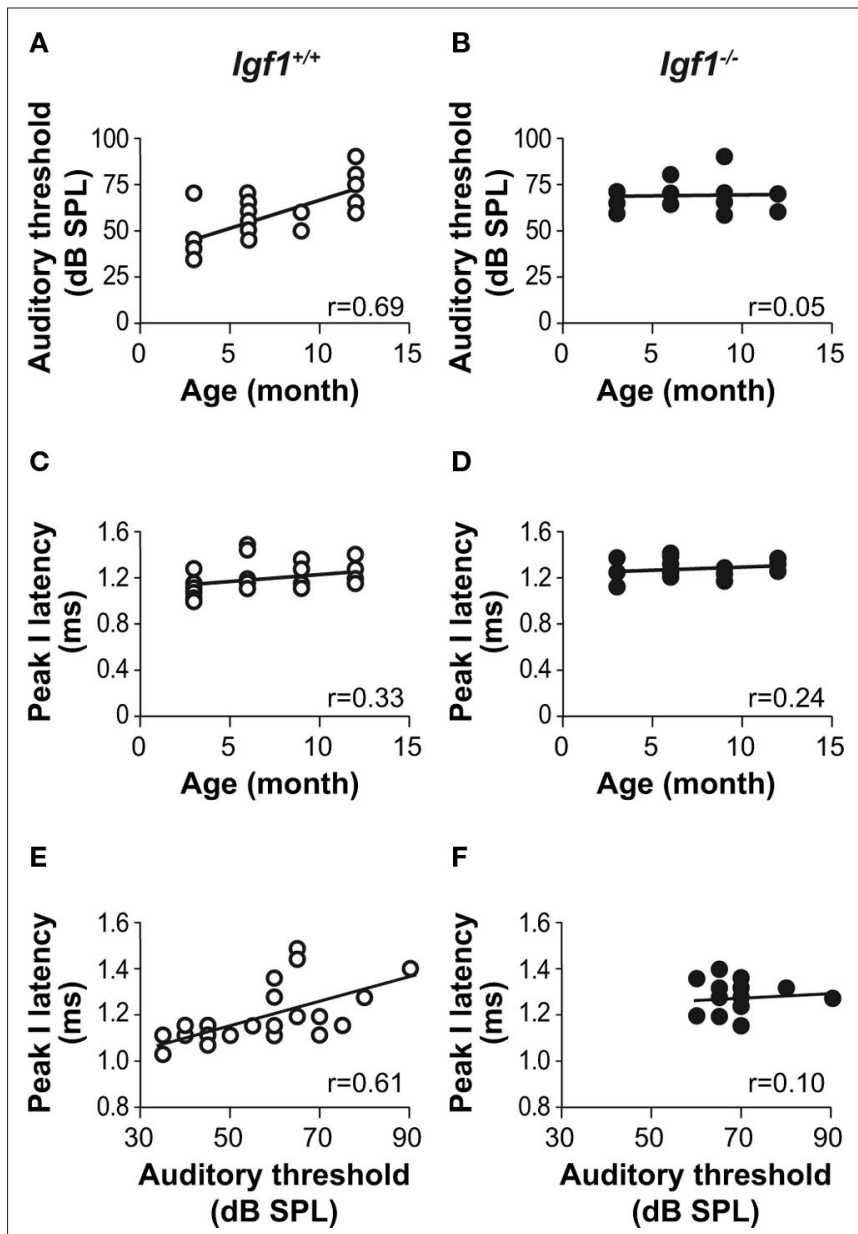

FIGURE 4 | Correlations between auditory thresholds and peak response latencies with aging and genotype. Product moment Pearson correlation coefficients were calculated for the pairs of parameters indicated. A clear correlation was evident between $A B R$ thresholds and age in the $\operatorname{lgf}^{+/+}$mice [open circles; (A) $P<0.05 ; n=24 ; r=0.69$ ] but not in the $/ \mathrm{gf}^{-1-}$ mice [closed circles; (B) ns; $n=19 ; r=0.05]$. The absolute peak I latency was weakly correlated with age in both $\lg f 1^{+/+}$[(C) $\left.P<0.1 ; n=24 ; r=0.33\right]$ and $/ g f 1^{-/-}$[(D) $P<0.25 ; n=19 ; r=0.24$ ] mice. The Pearson product moment correlation coefficient between peak I absolute latencies and auditory thresholds at different ages in $/ g f 1^{+/+}$mice was statistically significant $(P<0.05)$ [(E) $P<0.05 ; n=24 ; r=0.61]$. The same correlation in $\lg f 1^{-1-}$ mice was not statistically significant. [(F) ns; $n=19 ; r=0.09]$.

glion neurons that progressed with aging, an alteration that might represent the anatomical basis for the elevation in the age-related hearing threshold and the delay in the absolute peak I latency. The morphology of the cochlea from $I g f 1^{-/-}$null mice did not change with age and the altered postnatal traits already reported persisted, in agreement with the functional ABR results. Indeed, there was a progressive degeneration of the stria vascularis in $\mathrm{Igf1}^{-{ }^{-}}$mice from 3 months of age, but not in control wild type mice, which was shorter, thicker and with aberrant vascularization including dilated intra-strial capillaries when compared with that in the control Igf1 ${ }^{+/+}$mice (Figures 6A-H). Kir4.1 (Figures 6I-K) and Na-K-ATPase levels (compare Figures 6A,E with Figures 6B,F) in 3- and 12-month-old $I g f 1^{-1-}$ null mice reflected the important alterations in the stria vascularis. 


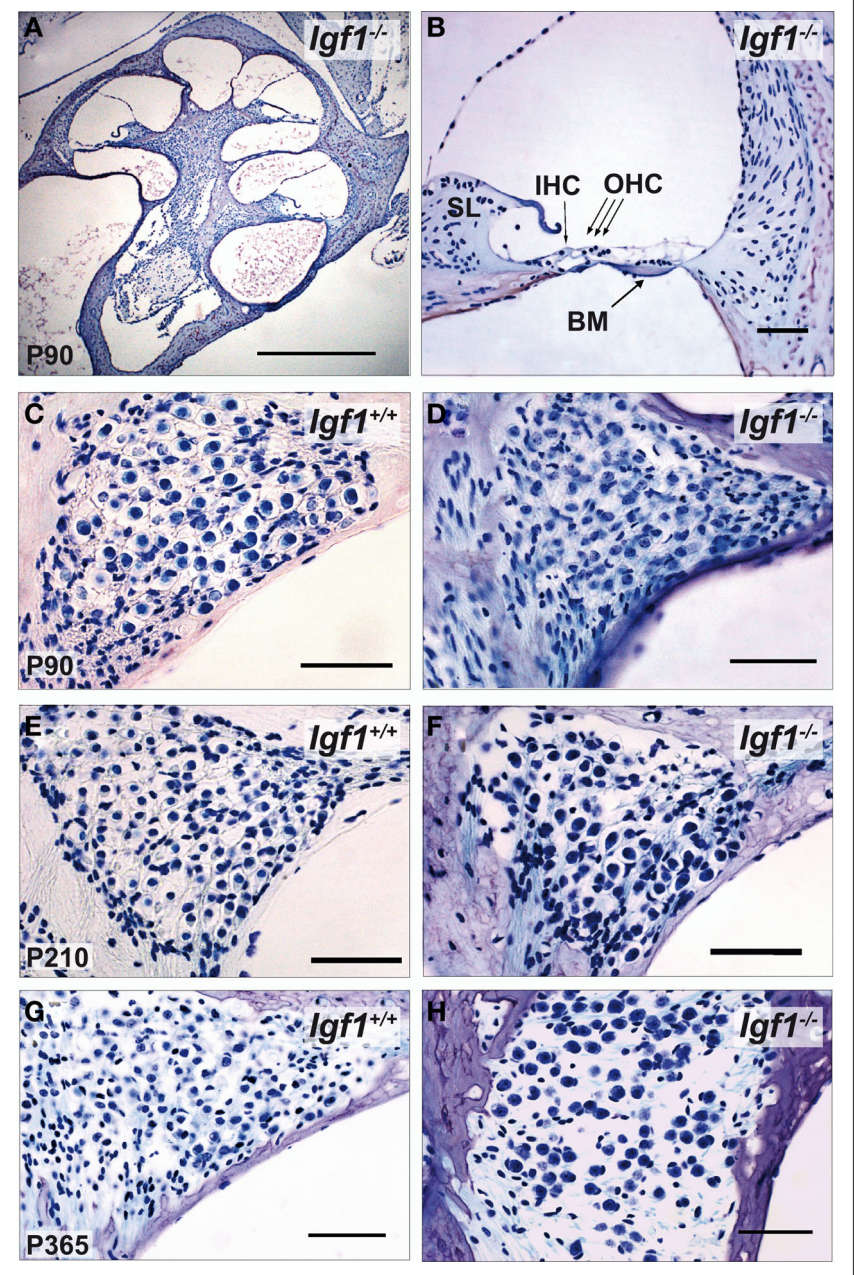

FIGURE 5 | Comparative study of cochlear morphology with aging in Igf $\mathbf{1 + / +}^{+\mathbf{w i l d}}$ type and $/ \boldsymbol{g} \mathbf{f 1}^{-/-}$null mice. $(\mathbf{A}, \mathbf{B})$ Cochlear cross-section and close up of the cochlear basal turn in a representative 3-month-old null mice. The disposition of the cells in the organ of Corti is apparently normal. IHC: inner hair cell; OHC: outer hair cells; BM: basilar membrane. (C-H) Comparison in both genotypes of the spiral ganglion morphology and of the neuronal density in mice at the ages studied. The neuronal density decreased in the aged spiral ganglion, such that at the older ages studied the cochlear ganglia was morphologically similar in both genotypes. Some specimens displayed heavy hair cell loss at this age, which was correlated with the increase in hearing thresholds (data not shown). Scale bar $50 \mu \mathrm{m}$ [0.5 $\mathrm{mm}$ in (A)].

\section{AGE-RELATED CHANGES IN BODY WEIGHT, CIRCULATING IGF-I LEVELS AND BRAIN WEIGHT}

The body weight of $I g f 1^{+/+}$and $I g f 1^{-/-}$null mice was measured at 1, 3, 6 and 12 months of age and both genotypes experienced an age-related increase in body weight. As expected, at all the ages studied the $I g f 1^{-/-}$mice were lighter than the $I g f 1^{+/+}$mice (Figure 7A). The greatest increase in body weight occurred at younger ages, between 1 and 3 months of age in both genotypes, whereas from 3 to 9 months of age their body weight reached a plateau and showed only minor increases. Indeed, there was a tendency to lose weight between 9 and 12 months in the wild type mice. Moreover, a significant correlation was identified between body weight and age.
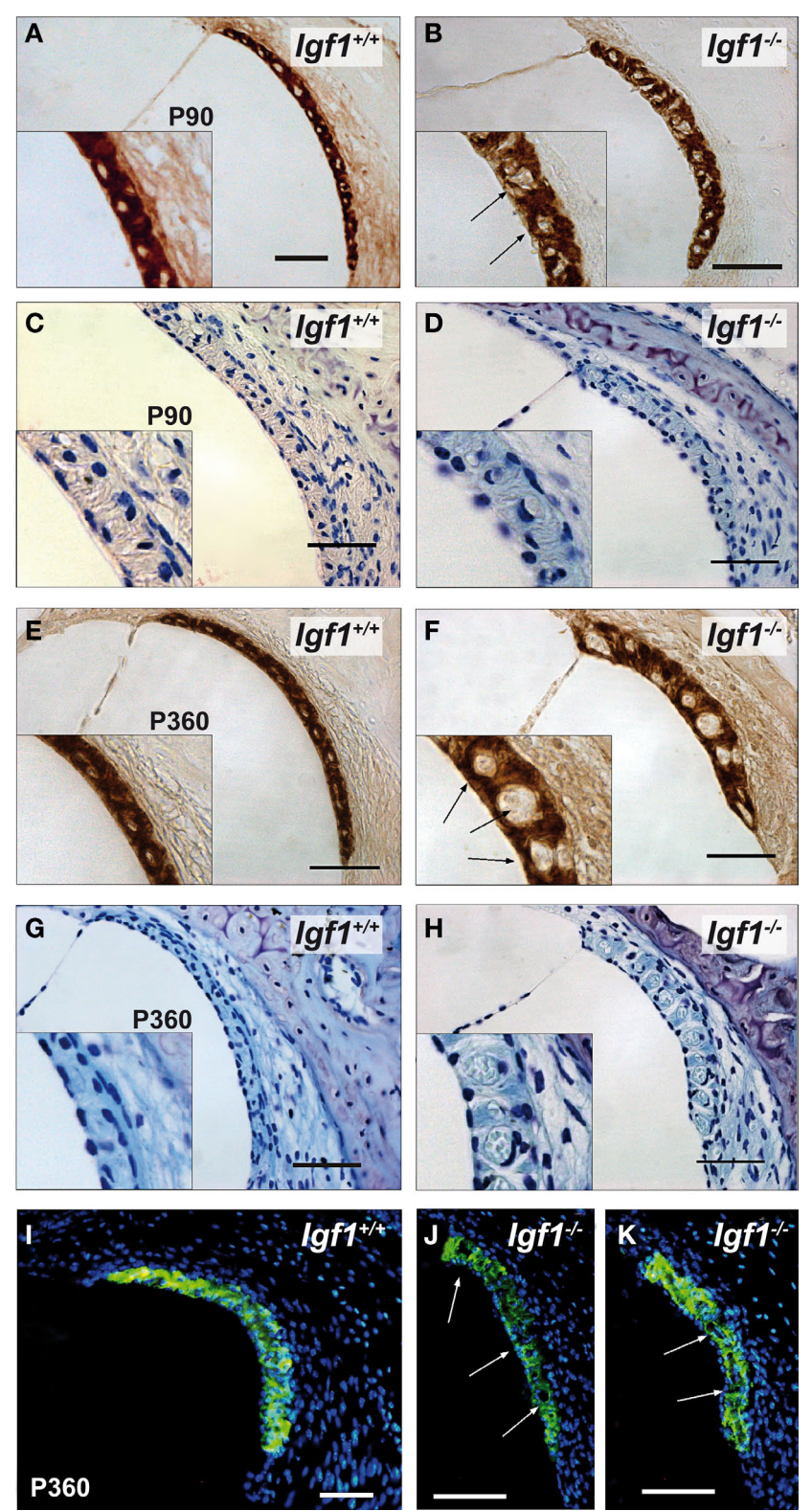

FIGURE 6 | Comparative study of the stria vascularis with the aging of Igf $\mathbf{1}^{\mathbf{+ /}}$ wild type and $/ \boldsymbol{g} \mathbf{f 1}^{-/-}$null mice. Na-K-ATPase $(\mathrm{A}, \mathrm{B}, \mathrm{E}, \mathrm{F})$ and cresyl violet staining $\mathbf{( C , D , G , H ) ~ e x p r e s s i o n ~ i n ~ t h e ~ s t r i a ~ v a s c u l a r i s ~ o f ~} 3-(\mathbf{A}-\mathbf{D})$ and 12-month-old mice (E-H) showing the morphological differences associated with the aging of each genotype. The stria vascularis in the $\lg \mathrm{ft}^{-1-}$ mice had an abnormal morphology, it was shorter and thicker, and with evident dilation of the vascular spaces (arrows). Kir4.1 (KCNJ10) expression (I-K) in the stria vascularis of aged null mice was altered and there was a relative loss of expression in the stria and sacular dilations. Four to six mice per condition were analyzed. Scale bar $50 \mu \mathrm{m}$.

Sera from wild type and null mice were collected at several times between 1 and 10 months of age to analyze the circulating IGF-I levels using a specific ELISA assay. An age-related decline in IGF-I was observed in $\mathrm{Igfl}^{+/+}$mice (Figure 7B), from the initial IGF-I levels in 1 -month-old mice $(1004 \pm 220 \mathrm{ng} / \mathrm{ml})$ to those in 10-month-old mice $(517 \pm 151 \mathrm{ng} / \mathrm{ml}, P<0.05)$. These progressive age-related 


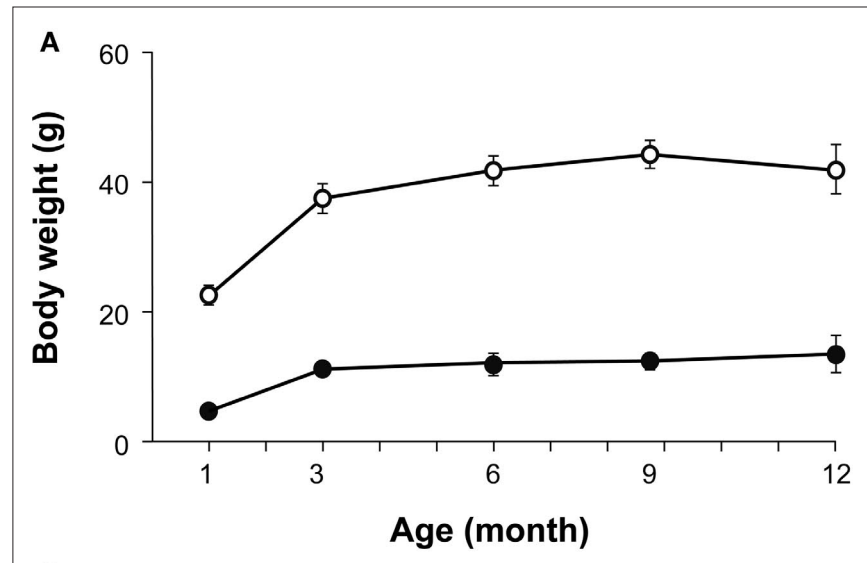

C

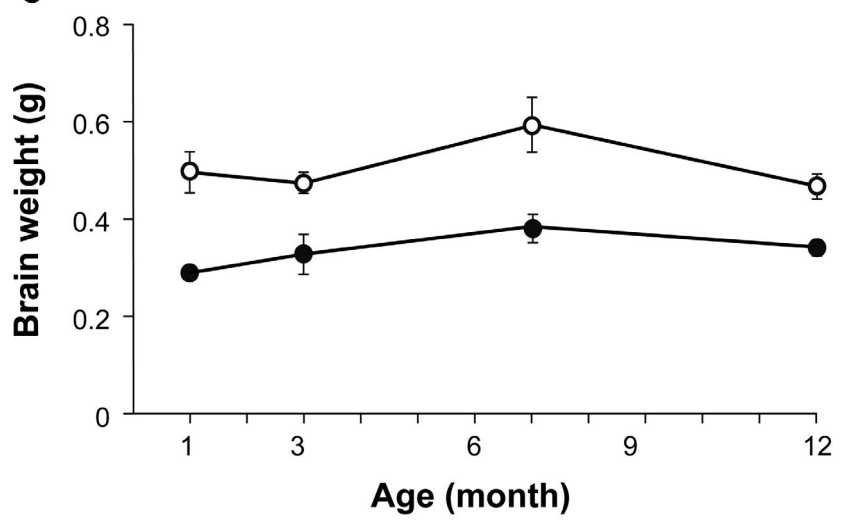

FIGURE 7 |A comparison of age-related changes in IGF-I levels, and body and brain weight in both genotypes. (A) Body weight of $/ \mathrm{gfl}^{1 /+}$ (open circles) and $/ \mathrm{gf1}^{-/-}$null (closed circles) mice was measured at 1, 3, 6 and 12 months of age. Statistical analysis in (A) and (C) was performed with ANOVA and post hoc Bonferroni and Dunnet tests. Data are presented as the mean \pm s.e.m. Both genotypes presented a significant difference at all the ages studied $(P<0.001)$ and an age-related increase in body weight. (B) The serum IGF-I levels were followed during aging in $\lg f 1^{+/+}$and $/ g f 1^{-/-}$mice in parallel. An age-related decline in serum IGF-I was observed in wild type mice (open circles) whereas no IGF-I

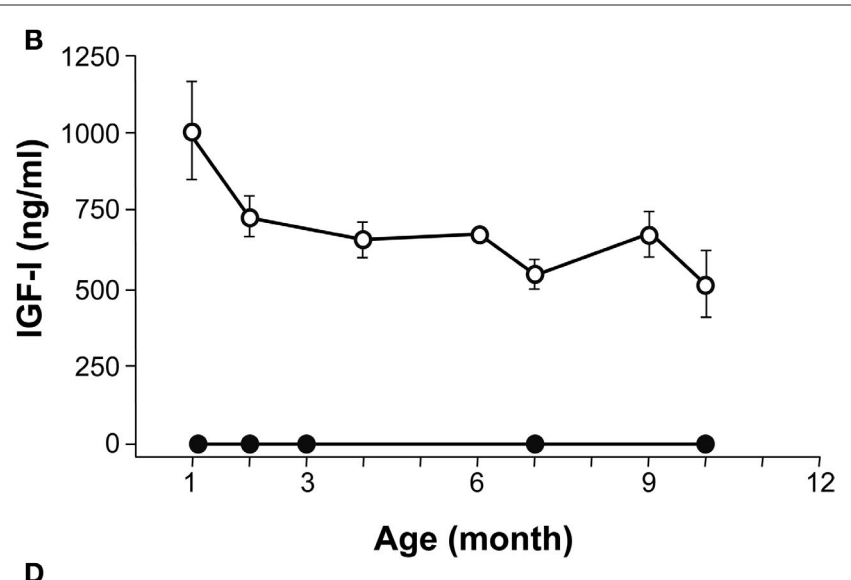

D

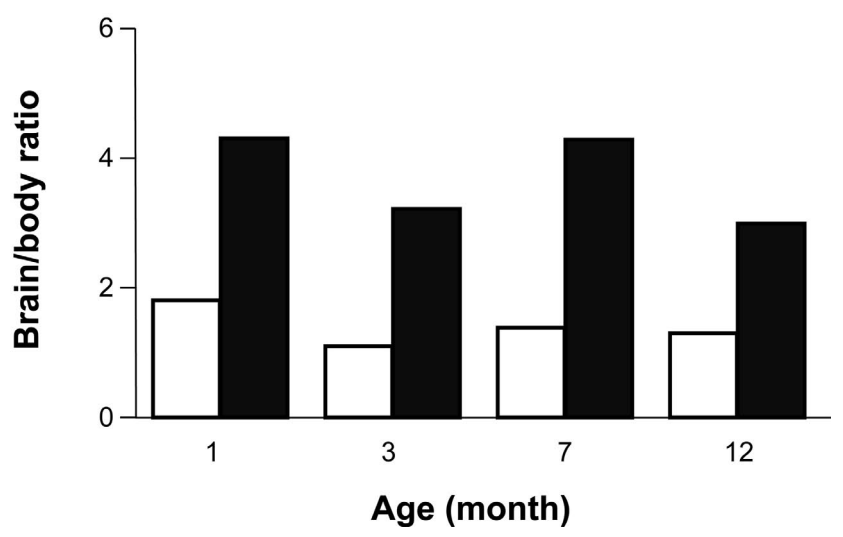

could be detected at any time in the null mice (closed circles). Data are given in $\mathrm{ng} / \mathrm{ml}$ as median \pm s.e.m. At least six to eight mice were studied per group. (C) Brain weight measurements did not change significantly as the mice aged, although there was a significant difference between the two genotypes at the ages studied ( $P<0.05)$. (D) The brain/body weight ratio was calculated for each age group of $\operatorname{lgf1^{+/+}}$ wild type (black bars) and $/ g f 1^{-1-}$ null mice (white bars). This ratio did not vary with age in any genotype. The number $(n)$ of mice studied in (A), (C) and (D) were 19, 7, 9, 8 and 5 wild type and 8, 6, 7, 6 and 5 null mice of 1, $3,6,9$ and 12 month old, respectively. decline in serum IGF-I levels mirrored the changes in body weight. By contrast, no detectable levels of IGF-I were measured at any time in the $I g \mathrm{fl}^{-/-}$null mice. IGF-I levels decline data were compared with those of increasing ABR thresholds (Figure 2A) in the different groups of wild type mice studied between 1 and 10 months. This comparison strongly suggest that there is a correlation between both parameters (Pearson $r=-0.33$; $n=35 ; P<0.05$ ).

Unlike body weight, brain weight measurements did not noticeably change as the animals aged, neither in $\operatorname{Igf1^{+/+}}$ nor $\operatorname{Igf1^{-/-}}$ null mice (Figure 7C). The brain/body weight ratio was calculated for each age group of wild type and null mice and the ratio was higher for $I g \mathrm{fl}^{-/-}$null mice than for wild type mice (Figure 7D). At each age tested, the $\operatorname{Igf1^{+/+}}$ mouse brain represented less than $2 \%$ of the total body weight, whilst the $I g f 1^{-1-}$ null mouse brain represented roughly $4 \%$ of their total body weight. Aging did not seem to affect these ratios, although the results indicated that there was an agerelated tendency towards a small reduction in the brain to body weight ratio.

\section{AGE-RELATED AND GENOTYPE-DEPENDENT BRAIN MORPHOLOGY}

In vivo serial MRI of the brain has provided valuable insights into the changes associated with a range of neurodegenerative and aging conditions (Liu et al., 2003; Paul et al., 2009). MRI is a non-invasive procedure that allowed both mouse populations to be studied in parallel with the hearing tests to further study the brain areas participating in auditory processing (Figures $\mathbf{8 A - C}$ ). Stereological procedures were used to calculate areas and volumes from the MRI images, and to analyze their progress over time (Figure $\mathbf{8 B}$ and Table 1). The gross brain morphology was similar between wild type and null mice, taking into account the difference in size, and except for the OB (Figure S2 in Supplementary Material), all the main brain regions that could be observed in the wild type mice were also observed in the null mice (Figure 8C). Brain images were obtained from 3-, 6-, 9- and 12-month-old wild type and null mice, and the volumes of the whole brain and selected brain parts were obtained. Since it was not possible to identify the auditory BS, the whole BS was considered as an individual part, and this region 


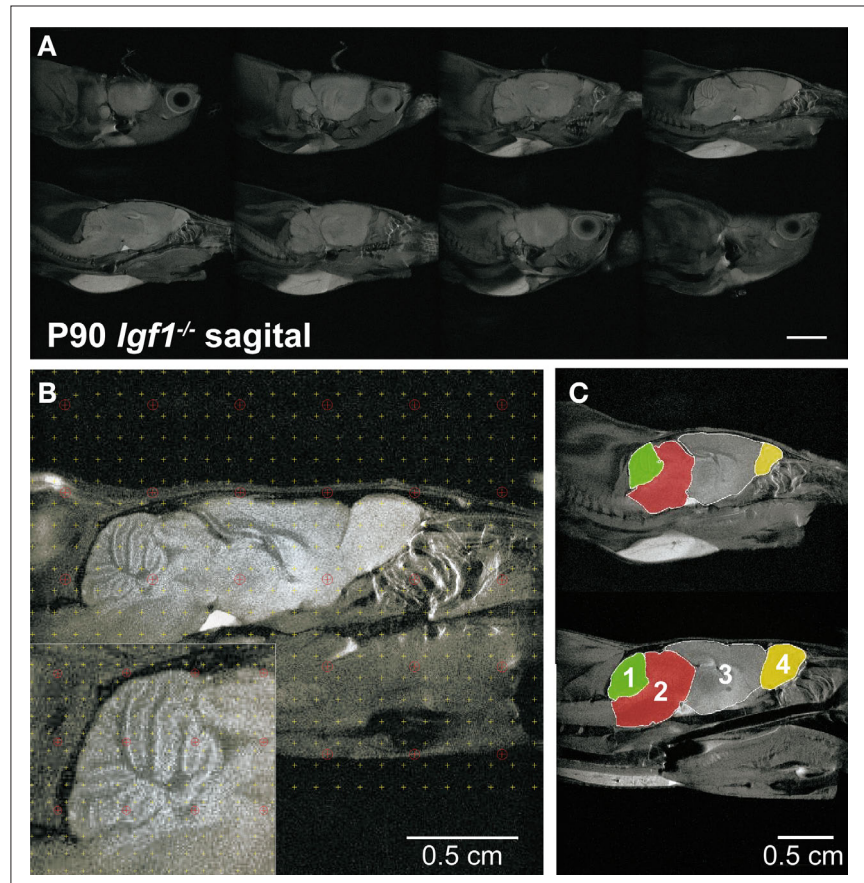

FIGURE 8 | In vivo brain images of $/ g f \mathbf{1}^{+/+}$wild type and $/ g f \mathbf{1}^{-/-}$null mice. (A) Complete series of brain slices in the sagittal plane of a representative 3-month-old lgf1-t- null mouse. (B) Sagittal MRIT2 weighted image of a representative 3-month-old wild type mouse showing the stereological grid that was randomly overlaid on each slide to estimate the volume. The inset shows the specific grid used to estimate the volume of specific brain areas, such as the cerebellum. (C) Comparison of the selected brain areas of $\lg \mathrm{f1}^{-t_{-}}$and $\operatorname{lgf1^{+/+}}$ mice: cerebellum (1), brainstem (2), diencephalon-telencephalon (3) and olfactory bulb (4). Note the reduced olfactory bulb in the deficient mice (yellow).

was considered as a representative region for auditory information processing. The $\mathrm{CBL}$ and the $\mathrm{OB}$ were included for comparison (Figure 8C). The relative BS volumes were similar in $I g f 1^{+/+}$and Igf1 $1^{-1-}$ null mice, and these volumes did not changed with aging in either genotype (Table 1). No other morphological alterations were observed by MRI at the BS level. A different orientation of the cochlea with respect to the brain was observed when comparing wild type and null mice (Figures S2A,B in Supplementary Material). At all the ages studied, the $\mathrm{OB}$ was the brain structure that showed the most important differences between wild type and null mice, as well as an aberrant laminar structure in the $I g f 1^{-/-}$ null mouse (Figures S2C,D in Supplementary Material; Table 1). Finally, there was a clear alteration of the ventricular system in the null mouse brain (Figures S2E,F in Supplementary Material). No evident age-related changes in brain morphology were observed in either genotype (Table 1).

The data presented above suggest that different brain areas may have distinct expression of IGF-I or that they may possess distinct compensatory mechanisms. Indeed, the Igfl gene is widely expressed in the mouse brain, albeit with regional variations in the levels of expression. Here, we quantified the Igf1 mRNA levels in four regions of the adult P90 mouse brain by quantitative RT-PCR. The highest levels of Igfl expression were in the OB (Figure S3 in Supplementary Material) where there were 5-fold more Igf1 transcripts than in the BS, and 10-fold more than in the TD (excluding the OB) and CBL. Null mouse brain did not express Igf1 as expected (data not shown). Since brain size is less strongly affected by Igfl deletion than the size of the rest of the body, we examined the possible compensatory effect of up-regulating Igflr and/or Igf2 expression in the brain. Igflr and Igf2 mRNA expression were analyzed by RT-qPCR in the four brain regions and they were not significantly different in $I g f 1^{-/-}$null mice than in the wild type mice (Figures 9A,B).

\section{DISCUSSION}

IGF-I is a member of the family of insulin-related peptides that fulfils a prominent role in the development of the central nervous system and in adult neurogenesis. Circulating levels of IGF-I decrease with age, this reduction being related to age-associated cognitive and brain alterations. Congenital mutations in the gene coding for IGF-I cause sensorineural deafness in mice and men, although it is not known whether hearing loss in the elderly population is related to the age-dependent reduction in IGF-I levels.

It is shown here that $I g f 1^{+/+}$wild type MF1/129/sv mice suffer age-related progressive elevation in hearing thresholds, which by the age of 1 year old reaches that presented at birth by the $I g f 1^{-1-}$ null MF1/129/sv mouse. From 1 to 12 months of age, the click-ABR thresholds of $I g f 1^{+/+}$mice experienced a progressive elevation of $30 \mathrm{~dB}$ SPL, which was paralleled by the progressive decrease in circulating IGF-I levels. The Igf1 ${ }^{-1-}$ null mouse has elevated auditory thresholds, and morphological alterations in the auditory receptor and spiral ganglion could account for this functional disorder (Camarero et al., 2001; Cediel et al., 2006; Sanchez-Calderon et al., 2010).

Age-related hearing loss is characterized by a progressive deterioration of hearing sensitivity with increasing age, and it has been studied in mice of different strains (Zheng et al., 1999; Ouagazzal et al., 2006; Niu et al., 2007). The mice used in the present study are on a hybrid genetic background of MF1 and 129/sv mouse strains, and they present mild hearing loss when compared to mice on other genetic backgrounds. By contrast, the 1-month-old $\mathrm{Igf1}^{-/-}$null mouse is already deaf and does not present significant threshold variations as it ages.

In both $I g f 1^{+++}$and $I g f 1^{-/-}$null mice the absolute latencies for waves I through IV show age-related increments, although the increment was larger in the $I g f 1^{+++}$than in the $I g f 1^{-/-}$null mice, especially the peak I latency. These data confirm that the increase in peak I latency is a trait associated with hearing loss in the mouse, as reported in other mammals such as man (Rosenhall et al., 1986; Cooper et al., 1990; Martini et al., 1990; Ingham et al., 1998; Torre and Fowler, 2000; Burkard and Sims, 2002). However, the effect of aging on IPL is not yet clear. Many authors have reported that the interpeak I-V latency is prolonged in the elderly (Rosenhall et al., 1986; Cooper et al., 1990; Fraenkel et al., 2003), whilst others argue that aging is not associated with a delay in the central conduction time (Martini et al., 1990; Burkard and Sims, 2002). Neither the $I g f 1^{-/-}$nor the wild type mouse show significant variations in IPL, since IPL I-II shows a small increase and IPL I-IV a small compensatory decrease, neither of which are significant. These data suggest that aging has no effect on the central conduction time, in contrast with the acute impact of aging on auditory receptor 
Table 1 | Body and brain of $/ g f 1^{-/-}$and $/ g f 1^{+/+}$mice with age.

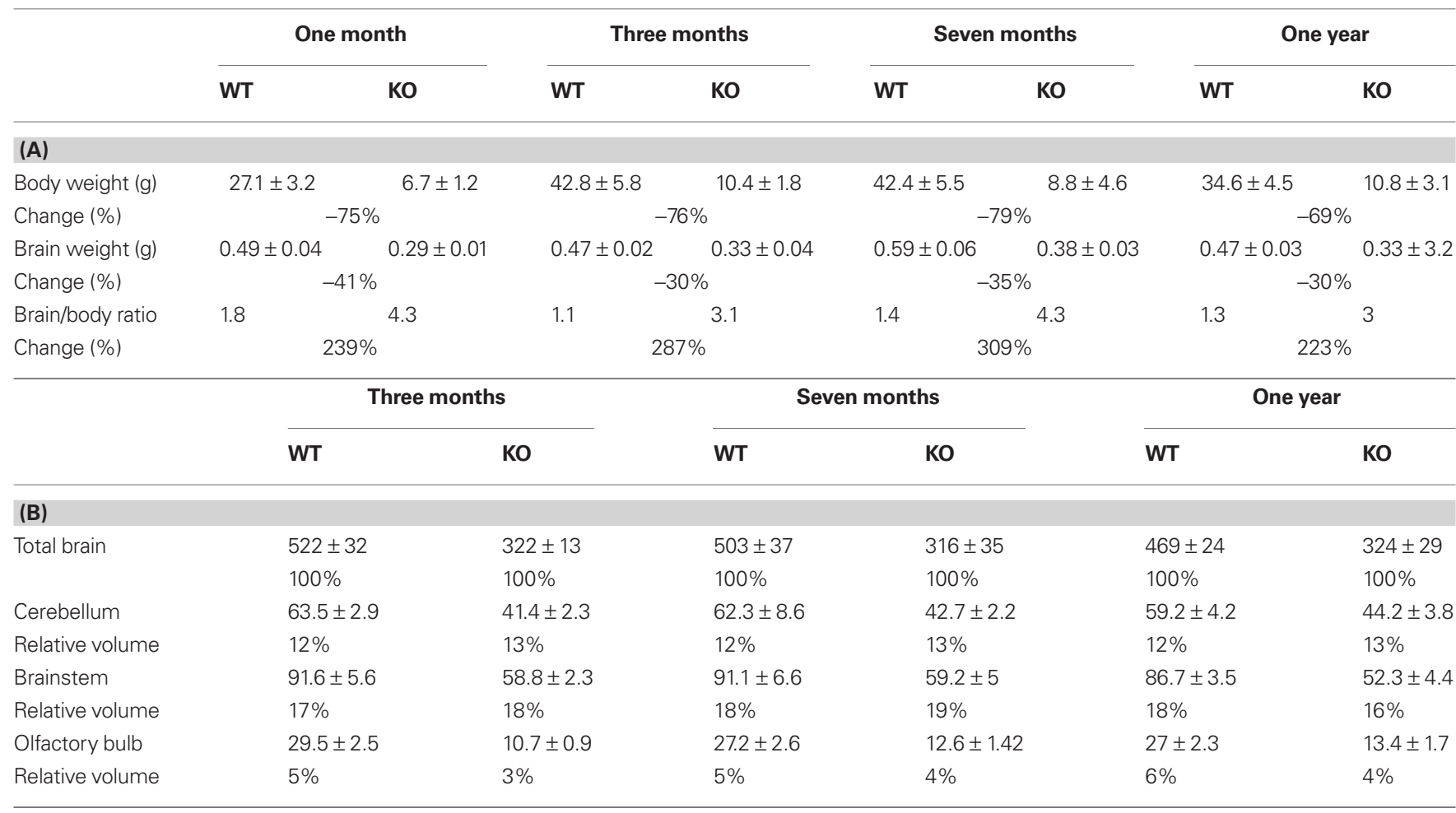

(A) Body and brain weights of lgf1-- $(K O)$ and lgf1+/+ $(W T)$ mice with aging. Brains were weighed after cutting off the medulla at the beginning of spinal cord. The values are represented as the mean \pm s.e.m. of at least four to six animals from each condition. An statistically significant difference between both genotypes $(P<0.001)$ was found at all the ages studied. Change $(\%)$ indicates the \% difference of each parameter between both genotypes, $100 \%$ corresponds to the wild type value.

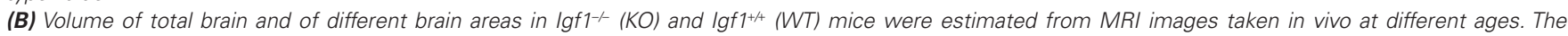
volume estimates were obtained by stereological analysis according to the Cavalieri principle (Gundersen and Jensen, 1987). Volumes are expressed in mm ${ }^{3}$ as the mean \pm s.e.m. of at least five animals for each genotype and age.

Relative volume indicates the \% of the total brain volume that each brain area represents, being $100 \%$ the brain volume of each genotype at each age studied. When genotypes were compared, a reduction in the olfactory bulb of the lgf $1^{-1}$ deficient mice but not in the other structures was observed.

function that is associated with a loss in spiral ganglion cell density. Age-related modification of ABR parameters has been associated with increased auditory thresholds, whereas a tendency toward increased ABR latencies has only been reported when threshold increases were considerable (Hunter and Willott, 1987). Our data support these concepts and indeed, the correlation analysis shows that the increase in ABR latency with age is strongly related to the elevated thresholds.

The auditory alterations detected by physiological procedures have morphological substrates. We previously showed that the cochlea of 1-month-old $I g f 1^{-1-}$ mice have morphological alterations that correlate with their elevated auditory thresholds (Camarero et al., 2001, 2002; Cediel et al., 2006). When compared to the wild type, Igf1 $1^{-/-}$null mice have smaller cochlea and cochlear ganglion, with a significant decrease in the number and average size of cochlear ganglion neurons (Camarero et al., 2001, 2002). With aging, the altered cochlear morphology in $I g f 1^{-/-}$mice persists yet neuronal loss does not progress, indicating that the early phenotype of neuronal loss was not premature neurodegeneration but rather a failure in the late developmental program. A transcriptome study of the null mouse cochlea confirmed that the differentiation of neural cells and structures is delayed at birth (Sanchez-Calderon et al., 2010). However, the Igf1 $1^{+/+}$cochlear ganglion suffers age-related neuronal loss, reaching levels that are similar to that of the neonatal $\operatorname{Igf1^{-1-}}$ mice. These data suggest that a subpopulation of auditory neurons depend on IGF-I for their final differentiation and/or for their survival, although most adult cochlear neurons can survive in the absence of this factor. Accordingly, cochlear neurons of $I g f 1^{+/+}$mice die as they age with a time-course that follows the decay in circulating IGF-I levels.

Cochlear degeneration has been associated with a down-regulation of IGF-I levels and aging in other models of ARHL (Riva et al., 2007). No hair cell loss was evident in either genotype at the ages studied but interestingly, a lack of IGF-I caused long-term degeneration in the stria vascularis, the metabolic center of the cochlea. This phenomenon is reminiscent of the diabetic cochlear phenotype also seen in the insulin receptor substrate 2 null mice (unpublished observation). Degeneration of the stria vascularis is one of the most prominent aspects in the pathophysiology of presbycusis in several species (Schulte and Schmiedt, 1992; Spicer and Schulte, 2002; Spiess et al., 2002). The variations in absolute latency with age show that the increase in latency is age-related in both genotypes and thus, the impact of IGF-I deficiency in the central auditory pathways was further explored in a longitudinal in vivo brain MRI study. Several important alterations were observed and since the gross morphology of the null mouse brain was maintained, brain size was less affected by the loss of IGF-I than body weight, and no differences were associated 

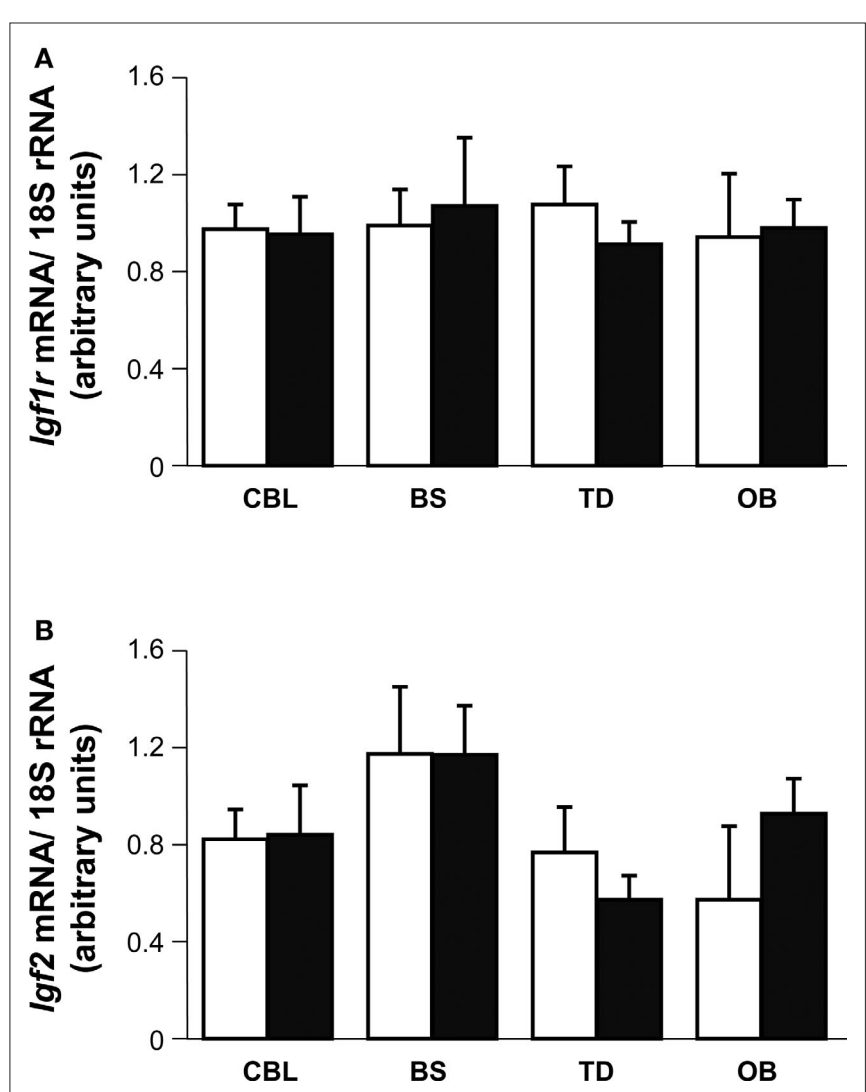

FIGURE 9 | Brain distribution and expression of Igf2 and Igf1r. Igf1r (A) and Igf2 (B) mRNA levels were measured by quantitative RT-PCR of RNA from the indicated mouse brain regions and normalized to the levels of the 18 S ribosomal RNA 3-5 mice per genotype were used. The results represent the mean \pm s.d. Brainstem (BS), olfactory bulb $(O B)$, cerebellum $(C B L)$ and the remainder of the telencephalon-diencephalon (TD). Open and closed bars indicate $\operatorname{lgf1^{+/+}}$ and $\operatorname{lgf1^{-/}}$ mice, respectively.

with aging. In man, several aging related changes in MRI brain volume have been seen, although we failed to detect such changes in the mice studied here (Liu et al., 2003; Paul et al., 2009).

Age-related $\mathrm{ABR}$ and morphological alterations to the cochlea were clear in the $I g f 1^{+/+}$but not in the $I g f 1^{-/-}$mice, suggesting that the decreasing levels of IGF-I during aging of wild type mice play a role in the rising thresholds and thus, in promoting the delay in latency (Leifke et al., 2000; Gomez, 2007). The $I g f 1^{-1-}$ null mouse shows hearing loss at young ages (ABR threshold $70 \mathrm{~dB}$ SPL), which

\section{REFERENCES}

Aberg, D. (2010). Role of the growth hormone/insulin-like growth factor 1 axis in neurogenesis. Endocr. Dev. $17,63-76$.

Aleman, A., and Torres-Aleman, I. (2009). Circulating insulin-like growth factor I and cognitive function: neuromodulation throughout the lifespan. Prog. Neurobiol. 89, 256-265.

Barrenas, M., Landin-Wilhelmsen, K., and Hanson, C. (2000). Ear and hearing in relation to genotype and growth

persisted throughout the 1-year period studied here and that did not deteriorate with age as in the $I g f 1^{+/+}$mice. It might be speculated that the lack of IGF-I itself has a protective role since low IGF1R activity has been associated with caloric restriction, delayed aging and extended lifespan in several species, including mice and humans (Weindruch and Sohal, 1997; Shimokawa et al., 2003; Bartke, 2005; Berryman et al., 2008; Salminen and Kaarniranta, 2010). In mice, caloric restriction prevents late onset presbycusis that would otherwise occur in aging animals, and it also protects cochlear elements from degenerating such as spiral ganglion cells (Someya et al., 2007). Alternatively, the presence of compensatory mechanisms in chronic IGF-I deficiency could explain the persistence of the hearing phenotype in the Igf1 ${ }^{-l-}$ null mouse as it ages. No changes in the expression of related factors (e.g., insulin and IGF-II), or of the high affinity receptor IGF1R are evident, in the brain or cochlea of the null mouse when compared with the wild type mouse (see also Sanchez-Calderon et al., 2010), nor in other contexts (Moerth et al., 2007). Other compensatory factors, such as neurotrophins, may act during late development, leading to FoxM1 activation and cell cycle preservation (Sanchez-Calderon et al., 2007, 2010), which could explain the preservation of brain and cochlear size with respect to body size in the $I g f 1^{-1-}$ null mouse.

In summary, the $I g f 1^{-/-}$null mouse is a model of chronic IGF-I deficit that leads to cochlear neuronal loss and profound deafness from the onset of hearing. With aging, chronic IGF-I deficit caused premature degeneration of the stria vascularis that was not observed in wild type mice. These data suggest that IGF-I is a candidate factor to control cochlear metabolic demands and hence, adult hearing. Conversely, wild type mice show age-related hearing loss that was associated with progressive loss of neurons and that paralleled the reduction in serum IGF-I levels. These data suggest that IGF-I is an otic protector whose levels may predict ARHL.

\section{ACKNOWLEDGMENTS}

This work was partially supported by grants to IVN from DIGNA Biotech, the Ministerio de Ciencia e Innovacion (SAF2008-00470) and from the Fundacion Mutua Madrileña to IVN and JMZ. Silvia Murillo-Cuesta and Lourdes Rodriguez-de la Rosa hold contracts from CIBERER.

\section{SUPPLEMENTARY MATERIAL}

The Supplementary Material for this article can be found online at http://www.frontiersin.org/neuroscience/neuroanatomy/ paper/10.3389/fnana.2010.00027/

IGF-1 axis in lifespan and healthspan: lessons from animal models. Growth Horm. IGF Res. 18, 455-471.

Bonapace, G., Concolino, D., Formicola, S., and Strisciuglio, P. (2003). A novel mutation in a patient with insulin-like growth factor 1 (IGF1) deficiency. J. Med. Genet. 40, 913-917.

Bright, G. M., Mendoza, J. R., and Rosenfeld, R. G. (2009). Recombinant human insulin-like growth factor-1 treatment: ready for primetime. Endocrinol. Metab. Clin. North Am. 38, 625-638.
Burkard, R. F., and Sims, D. (2002). A comparison of the effects of broadband masking noise on the auditory brainstem response in young and older adults. Am. J. Audiol. 11, 13-22.

Camarero, G., Avendano, C., FernandezMoreno, C., Villar, A., Contreras, J., de Pablo, F., Pichel, J. G., and Varela-Nieto, I. (2001). Delayed inner ear maturation and neuronal loss in postnatal Igf-1-deficient mice. J. Neurosci. 21, 7630-7641.

Berryman, D. E., Christiansen, J. S., Johannsson, G., Thorner, M. O., and Kopchick, J. J. (2008). Role of the GH/
Camarero, G., Villar, M. A., Contreras, J., Fernandez-Moreno, C., Pichel, J. 
G., Avendano, C., and Varela-Nieto, I. (2002). Cochlear abnormalities in insulin-like growth factor-1 mouse mutants. Hear. Res. 170, 2-11.

Cediel, R., Riquelme, R., Contreras, J., Diaz, A., and Varela-Nieto, I. (2006). Sensorineural hearing loss in insulinlike growth factor I-null mice: a new model of human deafness. Eur. J. Neurosci. 23, 587-590.

Cooper, W. A., Jr., Coleman, J. R., and Newton, E. H. (1990). Auditory brainstem responses to tonal stimuli in young and aging rats. Hear. Res. 43, 171-179.

Christensen, K., Johnson, T. E., and Vaupel, J. W. (2006). The quest for genetic determinants of human longevity: challenges and insights. Nat. Rev. Genet. 7, 436-448.

D’Ercole, A. J., Ye, P., and O'Kusky, J. R. (2002). Mutant mouse models of insulin-like growth factor actions in the central nervous system. Neuropeptides 36, 209-220.

Dik, M. G., Pluijm, S. M., Jonker, C. Deeg, D. J., Lomecky, M. Z., and Lips, P. (2003). Insulin-like growth factor I (IGF-I) and cognitive decline in older persons. Neurobiol. Aging 24, 573-581.

Dror, A. A., and Avraham, K. B. (2009). Hearing loss: mechanisms revealed by genetics and cell biology. Annu. Rev. Genet. 43, 411-437.

Fraenkel, R., Freeman, S., and Sohmer, H. (2003). Susceptibility of young adult and old rats to noise-induced hearing loss. Audiol. Neurootol. 8, 129-139.

Gomez, J. M. (2007). Serum leptin, insulin-like growth factor-I components and sex-hormone binding globulin. Relationship with sex, age and body composition in healthy population. Protein Pept. Lett. 14, 708-711.

Gundersen, H. J., and Jensen, E. B. (1987). The efficiency of systematic sampling in stereology and its prediction. J. Microsc. 147, 229-263.

Holley, M. C. (2002). Application of new biological approaches to stimulate sensory repair and protection. Br. Med. Bull. 63, 157-169.

Hunter, K. P., and Willott, J. F. (1987). Aging and the auditory brainstem response in mice with severe or minimal presbycusis. Hear. Res. 30, 207-218

Ingham, N. J., Thornton, S. K., Comis, S. D., and Withington, D. J. (1998). The auditory brainstem response of aged guinea pigs. Acta Otolaryngol. 118, 673-680.

Jelsing, J., Rostrup, E., Markenroth, K., Paulson, O. B., Gundersen, H. J., Hemmingsen, R., and Pakkenberg, B. (2005). Assessment of in vivo MR imaging compared to physical sections in vitro - a quantitative study of brain volumes using stereology. Neuroimage 26, 57-65.

Leifke, E., Gorenoi, V., Wichers, C., Von Zur Muhlen, A., Von Buren, E., and Brabant, G. (2000). Age-related changes of serum sex hormones, insulin-like growth factor-1 and sexhormone binding globulin levels in men: cross-sectional data from a healthy male cohort. Clin. Endocrinol (Oxf) 53, 689-695.

LeRoith, D. (2008). Insulin-like growth factors and the brain. Endocrinology 149, 5951.

Liu, J. P., Baker, J., Perkins, A.S., Robertson, E. J., and Efstratiadis, A. (1993). Mice carrying null mutations of the genes encoding insulin-like growth factor I (Igf-1) and type 1 IGF receptor (Igflr). Cell 75, 59-72.

Liu, R. S., Lemieux, L., Bell, G. S., Sisodiya, S.M., Shorvon, S. D., Sander, J. W., and Duncan, J. S. (2003). A longitudinal study of brain morphometrics using quantitative magnetic resonance imaging and difference image analysis. Neuroimage 20, 22-33.

Llorens-Martin, M., Torres-Aleman, I. and Trejo, J. L. (2009). Mechanisms mediating brain plasticity: IGF1 and adult hippocampal neurogenesis. Neuroscientist 15, 134-148.

Martini,A., Comacchio, F., and Magnavita, V. (1990). Auditory evoked responses (ABR, MLR, SVR) and brain mapping in the elderly. Acta Otolaryngol. Suppl. 476, 97-103; discussion 104.

McDaniel, B., Sheng, H., Warner, D. S., Hedlund, L. W., and Benveniste, H. (2001). Tracking brain volume changes in C57BL/6J and ApoEdeficient mice in a model of neurodegeneration: a 5-week longitudinal micro-MRI study. Neuroimage 14, 1244-1255.

Moerth, C., Schneider, M. R., RennerMueller, I., Blutke, A., Elmlinger, M. W., Erben, R. G., Camacho-Hubner, C., Hoeflich, A., and Wolf, E. (2007) Postnatally elevated levels of insulinlike growth factor (IGF)-II fail to rescue the dwarfism of IGF-I-deficient mice except kidney weight. Endocrinology 148, 441-451.

Murillo-Cuesta, S., Contreras, J., Cediel, R., and Varela-Nieto, I. (2010a). Comparison of different aminoglycoside antibiotic treatments to refine ototoxicity studies in adult mice. Lab. Anim. 44,124-131.

Murillo-Cuesta, S., Contreras, J., Zurita E., Cediel, R., Cantero, M., VarelaNieto, I., and Montoliu, L. (2010b). Melanin precursors prevent premature age-related and noise-induced hearing loss in albino mice. Pigment Cell Melanoma Res. 23, 72-83.
Murillo-Cuesta, S., Garcia-Alcantara, F, Vacas, E., Sistiaga, J. A., Camarero, G. Varela-Nieto, I., and Rivera, T. (2009). Direct drug application to the round window: a comparative study of ototoxicity in rats. Otolaryngol. Head Neck Surg. 141, 584-590.

Narasimhan, S. D., Yen, K., and Tissenbaum, H.A. (2009). Converging pathways in lifespan regulation. Curr. Biol. 19, R657-R666.

Netchine, I., Azzi, S., Houang, M., Seurin, D., Perin, L., Ricort, J. M., Daubas, C., Legay, C., Mester, J., Herich, R. Godeau, F., and Le Bouc, Y. (2009). Partial primary deficiency of insulinlike growth factor (IGF)-I activity associated with IGF1 mutation demonstrates its critical role in growth and brain development. J. Clin. Endocrinol. Metab. 94, 3913-3921.

Niedernhofer, L. J., Garinis, G. A., Raams, A., Lalai, A. S., Robinson, A. R., Appeldoorn, E., Odijk, H., Oostendorp, R., Ahmad, A., van Leeuwen, W., Theil, A. F., Vermeulen, W., van der Horst, G. T., Meinecke, P. Kleijer, W. J., Vijg, J., Jaspers, N. G., and Hoeijmakers, J.H. (2006). A new progeroid syndrome reveals that genotoxic stress suppresses the somatotroph axis. Nature 444, 1038-1043.

Niu, X., Trifunovic, A., Larsson, N. G., and Canlon, B. (2007). Somatic mtDNA mutations cause progressive hearing loss in the mouse. Exp. Cell Res. 313 3924-3934.

Ouagazzal, A. M., Reiss, D., and Romand, R. (2006). Effects of age-related hearing loss on startle reflex and prepulse inhibition in mice on pure and mixed C57BL and 129 genetic background. Behav. Brain Res. 172, 307-315.

Paul, R., Grieve, S. M., Chaudary, B. Gordon, N., Lawrence, J., Cooper, N., Clark, C. R., Kukla, M., Mulligan, R. and Gordon, E. (2009). Relative contributions of the cerebellar vermis and prefrontal lobe volumes on cognitive function across the adult lifespan. Neurobiol. Aging 30, 457-465.

Ponton, C. W., Moore, J. K., and Eggermont, J. J. (1996). Auditory brain stem response generation by parallel pathways: differential maturation of axonal conduction time and synaptic transmission. Ear Hear. 17, 402-410.

Riva, C., Donadieu, E., Magnan, J., and Lavieille, J. P. (2007). Age-related hearing loss in $\mathrm{CD} / 1$ mice is associated to ROS formation and HIF target proteins up-regulation in the cochlea. Exp. Gerontol. 42, 327-336.

Rosenhall, U., Pedersen, K., and Dotevall, M. (1986). Effects of presbycusis and other types of hearing loss on auditory brainstem responses. Scand. Audiol. 15, 179-185.
Salminen, A, and Kaarniranta, K. (2010). Insulin/IGF-1 paradox of aging: regulation via AKT/IKK/ NF-kappaB signaling. Cell. Signal. 22, 573-577.

Sanchez-Calderon, H., Milo, M., Leon, Y and Varela-Nieto, I. (2007). A network of growth and transcription factors controls neuronal differentiation and survival in the developing ear. Int. J. Dev. Biol. 51, 557-570.

Sanchez-Calderon, H., Rodriguez-de la Rosa, L., Milo, M., Pichel, J. G., Holley, M., and Varela-Nieto, I. (2010). RNA microarray analysis in prenatal mouse cochlea reveals novel IGF-I target genes: implication of MEF2 and FOXM1 transcription factors. PLoS ONE 5, e8699. doi: 10.1371/journal. pone.0008699.

Schulte, B. A., and Schmiedt, R. A. (1992). Lateral wall $\mathrm{Na}, \mathrm{K}-\mathrm{ATP}$ ase and endocochlear potentials decline with age in quiet-reared gerbils. Hear. Res. 61, 35-46.

Shimokawa, I., Higami, Y., Tsuchiya, T., Otani, H., Komatsu, T., Chiba, T., and Yamaza,H. (2003). Life span extension by reduction of the growth hormoneinsulin-like growth factor-1 axis: relation to caloric restriction. FASEB J. 17, 1108-1109.

Someya, S., Yamasoba, T., Weindruch, R., Prolla, T. A., and Tanokura, M. (2007). Caloric restriction suppresses apoptotic cell death in the mammalian cochlea and leads to prevention of presbycusis. Neurobiol. Aging 28, 1613-1622.

Spicer, S. S., and Schulte, B. A. (2002) Spiral ligament pathology in quietaged gerbils. Hear. Res. 172, 172-185.

Spiess, A. C., Lang, H., Schulte, B. A., Spicer, S.S., and Schmiedt, R.A. (2002). Effects of gap junction uncoupling in the gerbil cochlea. Laryngoscope 112, 1635-1641.

Sun, L. Y., and Bartke, A. (2007). Adult neurogenesis in the hippocampus of long-lived mice during aging. $J$. Gerontol. A Biol. Sci. Med. Sci. 62, 117-125.

Torre, P., 3rd, and Fowler, C. G. (2000) Age-related changes in auditory function of rhesus monkeys (Macaca mulatta). Hear. Res. 142, 131-140.

Torres-Aleman, I. (2008). Mouse models of Alzheimer's dementia: current concepts and new trends. Endocrinology $149,5952-5957$

Torres-Aleman, I. (2010). Toward a comprehensive neurobiology of IGF-I Dev. Neurobiol. 70, 384-396.

Uchino, A., Noguchi, T., Nomiyama, K., Takase, Y., Nakazono, T., Nojiri, J., and Kudo, S. (2007). Manganese accumulation in the brain: MR imaging. Neuroradiology 49, 715-720. 
Van Eyken, E., Van Camp, G., and Van Laer, L. (2007). The complexity of agerelated hearing impairment: contributing environmental and genetic factors. Audiol. Neurootol. 12, 345-358.

van Wijk, E., Krieger, E., Kemperman, M. H., De Leenheer, E. M., Huygen, P. L., Cremers, C. W., Cremers, F. P., and Kremer, H. (2003). A mutation in the gamma actin 1 (ACTG1) gene causes autosomal dominant hearing loss (DFNA20/26). J. Med. Genet. 40, 879-884.

Varela-Nieto, I., Hartl, M., Gorospe, I., and Leon, Y. (2007). Anti-apoptotic actions of insulin-like growth factors: lessons from development and implications in neoplastic cell transformation. Curr. Pharm. Des. 13, 687-703.

Walenkamp, M. J., Karperien, M., Pereira, A. M., Hilhorst-Hofstee, Y., van Doorn, J., Chen, J. W., Mohan, S., Denley, A., Forbes, B., van Duyvenvoorde, H. A., van Thiel, S. W., Sluimers, C. A., Bax, J. J., de Laat, J. A., Breuning, M. B., Romijn, J. A., and Wit, J. M. (2005). Homozygous and heterozygous expression of a novel insulin-like growth factor-I mutation. J. Clin. Endocrinol. Metab. 90, 2855-2864.

Walenkamp, M. J., and Wit, J. M. (2007). Genetic disorders in the GH IGF-I axis in mouse and man. Eur. J. Endocrinol. 157(Suppl. 1), S15-S26.

Watanabe, T., Miyazaki, A., Katagiri, T., Yamamoto, H., Idei, T., and Iguchi, T. (2005). Relationship between serum insulin-like growth factor-1 levels and Alzheimer's disease and vascular dementia. J. Am. Geriatr. Soc. 53, 1748-1753.

Watanabe, T., Radulovic, J., Spiess, J., Natt, O., Boretius, S., Frahm, J., and Michaelis, T. (2004). In vivo 3D MRI staining of the mouse hippocampal system using intracerebral injection of MnCl2. Neuroimage 22, 860-867.

Weindruch, R., and Sohal, R. S. (1997). Seminars in medicine of the Beth Israel Deaconess Medical Center. Caloric intake and aging. N. Engl. J. Med. 337, 986-994.

Welch, D., and Dawes, P. J. (2007). Childhood hearing is associated with growth rates in infancy and adolescence. Pediatr. Res. 62, 495-498.
Woods, K. A., Camacho-Hubner, C., Barter, D., Clark, A. J., and Savage, M. O. (1997). Insulin-like growth factor I gene deletion causing intrauterine growth retardation and severe short stature. Acta Paediatr. Suppl. 423, 39-45.

Zeger, M., Popken, G., Zhang, J., Xuan, S., Lu, Q. R., Schwab, M. H., Nave, K. A., Rowitch, D., D’Ercole, A. J., and Ye, P. (2007). Insulin-like growth factor type 1 receptor signaling in the cells of oligodendrocyte lineage is required for normal in vivo oligodendrocyte development and myelination. Glia 55, 400-411.

Zheng, Q.Y., Johnson, K. R., and Erway, L. C. (1999). Assessment of hearing in 80 inbred strains of mice by ABR threshold analyses. Hear. Res. 130, 94-107.

Zhu, M., Yang, T., Wei, S., DeWan, A. T., Morell, R. J., Elfenbein, J. L., Fisher R. A., Leal, S. M., Smith, R. J., and Friderici, K. H. (2003). Mutations in the gamma-actin gene (ACTG1) are associated with dominant progressive deafness (DFNA20/26). Am. J. Hum. Genet. 73, 1082-1091.
Conflict of Interest Statement: The authors declare that the research was conducted in the absence of any commercial or financial relationships that could be construed as a potential conflict of interest.

Received: 31 March 2010; paper pending published: 20 April 2010; accepted: 01 June 2010; published online: 23 June 2010.

Citation: Riquelme R, Cediel R, Contreras J, Rodriguez-de la Rosa L, Murillo-Cuesta S, Hernandez-Sanchez C, Zubeldia JM, Cerdan S and Varela-Nieto I (2010) A comparative study of age-related hearing loss in wild type and insulin-like growth factor I deficient mice. Front. Neuroanat. 4:27. doi: 10.3389/fnana.2010.00027 Copyright (c) 2010 Riquelme, Cediel, Contreras, Rodriguez-de la Rosa, MurilloCuesta, Hernandez-Sanchez, Zubeldia, Cerdan and Varela-Nieto. This is an open-access article subject to an exclusive license agreement between the authors and the Frontiers Research Foundation, which permits unrestricted use, distribution, and reproduction in any medium, provided the original authors and source are credited. 